\title{
People of African descent and COVID-19: unveiling structural inequalities in Latin America
}

\section{Introduction ${ }^{1}$}

The global crisis that has led to the coronavirus disease (COVID-19) pandemic is having a heavy impact not only on health but also on economic, social and other areas, which, in turn, is exacerbating existing structural problems in all countries in the region. A number of Latin American countries have now become the epicentre of the pandemic and are topping the global statistics of daily cases (above Europe and the United States) and, in many, this indicator, which is key in the spread of the epidemic, has accelerated. Although many Latin American and Caribbean countries have established physical isolation measures to reduce infection and prevent health systems from collapsing, the region's structural problems make it more complex to mount an immediate response to the crisis (ECLAC/PAHO, 2020). A few Latin American countries (Brazil, Colombia, Peru, Mexico, Argentina and Chile) are among the world's 20 nations with the highest number of people infected with COVID-19. Brazil, Mexico, Peru, Colombia, Argentina, Chile and Ecuador are among the 20 nations with the most deaths from the disease. Panama, Chile, Peru, Brazil and Colombia are also on the list of the 20 countries with the highest number of confirmed cases per million inhabitants, and Peru, the Plurinational State of Bolivia, Brazil, Chile, Ecuador, Mexico, Panama and Colombia are among the 20 countries with the most deaths per million inhabitants (Worldometer, 2020). ${ }^{2}$

COVID-19 compounds the adversity and difficulties in all sorts of areas that are faced by people living in poverty, especially as this population experiences more severe problems of food security and access to basic and health services. Such problems include living in conditions of food insecurity and overcrowded housing, with poor access to safe water and no sanitation. This leads to a higher incidence of disease and comorbidities such as diabetes, high blood pressure and obesity, which increase the risk of both contracting COVID-19 and suffering complications once infected.

Many of these people are key workers providing essential services during the pandemic, such as cleaning, transport, courier services, storage and care. They cannot provide these services from home, making it difficult to comply with physical distancing measures and contributing to increased COVID-19 transmission. Many such jobs are informal and performed by people with no savings to tide them over in times of crisis and no access to social protection. The pandemic is therefore highlighting not only the urgent need to increase support for people living in poverty to enable them to withstand the most acute period of the crisis but also how imperative it is to combat poverty and inequalities in the medium and long term.

COVID-19 is exposing social inequalities of all kinds, as well as the overrepresentation of Afrodescendants among the group living in poverty who are employed in informal and caregiving jobs (ECLAC, 2017a and 2017b). As Afrodescendants have worse indicators of

\section{Introduction}

. Reasons why COVID-19 might be having a disproportionate impact on the Afrodescendent population

II. The Afrodescendent population and its vulnerability to COVID-19: what the data tell us

A. Poverty

B. Adequate housing and access to services

C. Education

D. Employment and income III. Actions to combat COVID-19 IV. Recommendations Bibliography
Unless otherwise indicated, the cut-off date for the information used to prepare this report is 31 August 2020. Countries are listed in descending order of the number of cases.

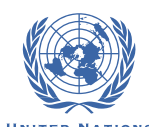

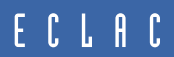

COVID-19 RESPONSE 
well-being than their non-Afrodescendent peers, ${ }^{3}$ they are seen as one of the groups most vulnerable to the COVID-19 pandemic, in terms of both infection and mortality. Various agencies and institutions, including the Pan American Health Organization (PAHO/WHO, 2020), the United Nations Population Fund (UNFPA, 2020), the Office of the United Nations High Commissioner for Human Rights (OHCHR, 2020), the Inter-American Development Bank (IDB, 2020), the Inter-American Commission on Human Rights of the Organization of American States (OAS, 2020a) and the Inter-American Network of High Authorities on Policies for Afro-descendant Populations (RIAFRO) (OAS, 2020b), have already pointed out that the Afrodescendent population is more vulnerable to COVID-19 owing to the structural inequality and racial discrimination to which it is subjected. While each of these agencies has put forward a range of recommendations to tackle the pandemic, most highlight the importance of implementing participatory policies that are culturally relevant, free from racism and promote equality and rights for all Afrodescendants.

Accordingly, this document analyses the specific situation of Afrodescendent populations and the effects that COVID-19 might be having on them, based on up-to-date empirical data and an ethnic/racial, generational, territorial, rights-based and gender approach. However, the availability of data sources disaggregated by ethnicity/race is still a challenge in the region and progress in identifying Afrodescendent populations in censuses, surveys and administrative records has been made only recently. Data disaggregation is an essential tool to highlight the inequalities exposed by this pandemic, and lack of disaggregated data makes it harder to ascertain the full health, social and economic impact of the pandemic on the Afrodescendent population (ECLAC, 2017a, 2017b and 2020b). Finally, this analysis has been prepared in line with the 2030 Agenda for Sustainable Development, ${ }^{4}$ the International Decade for People of African Descent (United Nations, 2014a), the Montevideo Consensus on Population and Development ${ }^{5}$ and the Regional Agenda for Inclusive Social Development, ${ }^{6}$ whose concerns include the Afrodescendent population and the fight against racism and ethnic and racial discrimination.

\section{Reasons why COVID-19 might be having a disproportionate impact on the Afrodescendent population}

The right to health is recognized in various international human rights instruments. They highlight the importance of addressing health from a comprehensive perspective that considers emotional, physical and social well-being, as defined by the World Health Organization (WHO), where the relationship between health and its social determinants is taken into account. The relevant chapter in the Durban Programme of Action urges countries to eliminate disparities in health status which might result from racism (United Nations, 2002). One of the goals of the 2030 Agenda is to promote physical and mental health and well-being and to extend life expectancy for all, without any form of discrimination. A priority action of the Montevideo Consensus is to ensure that Afrodescendent persons can exercise the right to health, taking into account the specific socioterritorial and cultural features and the structural factors, such as racism, that hinder the exercise of their rights. The Regional Agenda for Inclusive Social Development recognizes that Afrodescendants and their communities have the right to undertake direct actions to break down the multiple access barriers to health, which may include the application of a multiracial approach in health services.

Despite recognition of the right of Afrodescendants to equality in all areas, existing discriminatory and racist practices lead to worse living conditions for this population, especially in health matters. This makes it important for policies to be universal and

Throughout this document, the term "non-Afrodescendants" excludes indigenous people and, in the case of Brazil, refers to people who self-identify as white.

4 Adopted in 2015 by the vast majority of world leaders, who pledged, among other things, to fight for equality for all, without distinction of any kind, and to achieve sustainable development and more egalitarian societies where no one is left behind (United Nations, 2015).

5 Adopted at the first session of the Regional Conference on Population and Development in Latin America and the Caribbean, held in Montevideo in 2013. The shortened form, Montevideo Consensus, is used throughout the rest of the document (ECLAC, 2013b)

6 Adopted at the third session of the Regional Conference on Social Development in Latin America and the Caribbean, held in Mexico City in 2019 (ECLAC, 2020c) 
sensitive to differences, meaning not only should they extend to the general population, they should also include measures targeted specifically at the Afrodescendent population ${ }^{7}$ (ECLAC, 2020c). Indeed, health inequity is linked with unjust and avoidable social inequalities that can be overcome through appropriate, timely and participatory interventions.

The reasons why the pandemic might be affecting the Afrodescendent population disproportionately can be explained within the framework of the social determinants of health and the social inequality matrix. The position people occupy in the social hierarchy, coupled with characteristics such as gender, race or ethnicity, place of residence and intersectionality, determine people's growth, learning, work and ageing, as well as their vulnerability to diseases and chance of receiving treatment should they contract one. Accordingly, the choice of policies and economic and social development can affect health and health equity (PAHO/WHO, 2017). In turn, the social inequality matrix (ECLAC, 2016a) emphasizes the elements that structure and reproduce social inequalities and determine the circumstances in which people live. These elements are gender, ethnicity and race, place of residence and stage of life, together with aspects such as disability, immigration status, sexual orientation and gender identity. All this helps to explain how multiple and simultaneous forms of discrimination and exclusion lead to health inequalities that feed back into one another (intersectionality), as well as how certain sociocultural patterns, such as patriarchalism, racism, heteronormativity, stereotypes, disabilities and place of residence or origin, have a negative impact on health, calling for people to be considered more holistically (Abramo, Cecchini and Ullmann, 2019)

Below, some core indicators are used to illustrate the deep inequalities that exist between the Afrodescendent and non-Afrodescendent populations, which impact on health First there are sociodemographic indicators and indicators of health itself, followed by indicators relating to the social determinants of health and the spheres of rights and social development, which are affected by the structural determinants of the social inequality matrix. The Afrodescendent population's existing vulnerability is bound to worsen as a result of COVID-19, which may lead to an increase in ethnic and racial inequalities in the region.

\section{The Afrodescendent population and its vulnerability to COVID-19: what the data tell us}

According to the latest census figures for each Latin American country and 2020 estimates, 134 million people self-identify as being of African descent, which accounts for around $20.9 \%$ of the region's total population. ${ }^{8}$ Brazil is the country with the highest number of Afrodescendants (over 100 million, or more than half the population). As regards relative share, Afrodescendants are estimated to account for 95.5\% of Haiti's population (more than 10 million people), 36\% of Cuba's population (more than 4 million people) and between $7 \%$ and $10 \%$ of the population of a further five countries (Colombia, Costa Rica, Dominican Republic, Ecuador and Panama). In the other countries, Afrodescendants are estimated to account for less than $5 \%$ of the population. As regards numbers, there are an estimated 3.5 million Afrodescendants in Colombia and around 1 million in the Bolivarian Republic of Venezuela, the Dominican Republic, Ecuador, Mexico and Peru (ECLAC, 2020b).

As regards territorial distribution, Afrodescendent populations live predominantly in urban areas: the level of urbanization exceeds $70 \%$ in most countries and, in Uruguay, it is $97 \%$. Even though the Afrodescendent population is distributed nationwide, in some countries it is more concentrated in certain areas associated with historical settlements dating from the colonial period of slavery and with international or internal migration. Afrodescendants are also concentrated in remote areas that provided a haven for formerly enslaved people (ECLAC, 2017a and 2017b).

Governments in the region adopted this perspective by consensus at the third session of the Regional Conference on Social Development in Latin America and the Caribbean and it was made a central principle of the Regional Agenda for Inclusive Social Development, which was adopted on that occasion (ECLAC, 2020c).

8 The population estimate covers all 20 Latin American countries, based on population and housing censuses. The exceptions are Mexico, where the data relate to the 2015 inter-census survey, and the Dominican Republic and Haiti, where specific studies were used to calculate the approximate share of the Afrodescendent population. 
As regards the age structure, demographic transition is either complete or advanced among most Afrodescendent populations, mainly as a result of a decline in fertility, a reduction in mortality and an increase in life expectancy. This has been reflected in a gradual decrease in the number of children and young people and an increase in the number of adults and older persons, although the proportion of people of working age is still higher than the potential non-working population (ECLAC, 2017a and 2017b). In the context of COVID-19, while the Afrodescendent population is exposed to greater infection because it is more urban, this is counterbalanced by the fact that it is relatively younger than the non-Afrodescendent population, making it potentially less vulnerable.

As regards the indicators of health itself, an important example of racial inequality is the infant mortality rate, which is related directly to poverty levels and reflects severe inequalities, not only among countries but also within them. In Colombia, Uruguay, Panama and Brazil, for example, the probability of an Afrodescendent child dying before the age of one year is 1.3-1.6 times greater than that of a non-Afrodescendent child (ECLAC, 2017a and 2017b). Obesity, which is one of the comorbidities of COVID-19, is a disease associated with poor nutrition, which increasingly affects the most vulnerable population and also the Afrodescendent population. In the case of Brazil, a study carried out on the basis of the 2013 national health survey revealed that obesity is more prevalent among people with a low level of education and among people self-identifying as preto (black) (Ferreira, Szwarcwald and Damacena, 2019).

As regards the indicators of violence, the Afrodescendent population suffers more police violence and more deaths in encounters with police officers, is arrested and imprisoned more frequently and tends to be sentenced to harsher penalties. In 2017, the homicide rate among Brazil's Afrodescendent population was 43.1 per 100,000 people, compared with 16.0 among the non-Afrodescendent population. Among young Afrodescendants, the homicide rate was 69.9. Violence against women also affects Afrodescendent women to a greater extent. In Brazil in 2017, a total of 4,936 women were murdered, $66 \%$ of whom were Afrodescendants (IPEA, 2019). In the context of the pandemic, the "Favelas in the Fight Movement", made up of groups promoting rights, communication and access to public policies in the slums of the Brazilian state of Rio de Janeiro that are predominantly inhabited by Afrodescendent populations, denounced the militarization of slums and suburbs, underpinned by a "war on drugs" narrative, which results in the murder of young residents the vast majority of whom are Afrodescendants. The movement has also denounced the fact that, since the beginning of the pandemic, it is communities themselves that have organized to guarantee food for thousands of residents and bring down the curve of infection by distributing hygiene products and health guidelines. It has pointed out that police operations occur at times when basic baskets of goods are distributed and public health actions are carried out (Pires, 2020).

It is crucial to take into account all the above-mentioned points when designing policies, especially in times of COVID-19 when the intrinsic structural vulnerability of Afrodescendent populations is compounded by vulnerabilities arising from the disease. The sociodemographic elements discussed earlier (number of Afrodescendants, relative share, territorial distribution and age structure of the Afrodescendent population) are key to targeting policies and understanding how ethnic and racial inequalities overlap and are reproduced. As regards territorial distribution, in several instances the areas where Afrodescendent populations are concentrated are also countries' most depressed or least developed areas. Even where the places Afrodescendants live are not themselves the most disadvantaged areas (such as a large city), they are concentrated in deprived neighbourhoods, such as slums.

COVID-19 is a disease for which proper control demands physical distancing, frequent hand washing and efficient health services. In many cases, it also requires some economic activities to be shut down to reduce spread. For a large section of the population that needs to work to survive, this lockdown makes it hard to generate income, which is why they need economic support in the form of cash and in-kind transfers to enable them to comply with physical isolation measures. Situations like these are affecting Afrodescendants disproportionately because they are concentrated in urban centres and live in overcrowded housing in slums with inadequate sanitation and water services and poor access to health services. Furthermore, the Afrodescendent population experiences higher rates of violence, poverty, unemployment and informal employment and earns less (see box 1 describing the example of Brazil). 
Box 1

Brazil: overrepresentation of the Afrodescendent population among people hospitalized and deceased as a result of COVID-19

As of 19 July 2020, there were 2,098,389 confirmed cases of COVID-19 in Brazil and 79,488 deaths. These figures accounted for more than half the cases in the region (Ministry of Health of Brazil, 2020). The pandemic has exposed the wide racial inequalities that exist in the country. The figure below shows the evolution of deaths from severe acute respiratory syndrome caused by the new coronavirus between April and July, on the basis of Ministry of Health epidemiological bulletins. It shows that, at the outset, the disease affected mainly non-Afrodescendants but, in May, it was already having a greater impact on Afrodescendants, in a percentage exceeding their relative share of the total population (51\%, according to the 2010 census). Data such as these show that inequalities in access to health services, higher poverty rates and other conditions of increased socioeconomic vulnerability (such as greater overcrowding and less access to safe water and basic sanitation) are reflected in the health of Afrodescendants and undermine their ability to cope with coronavirus on an equal footing. A point of note is that Brazil's Federal Government has not implemented physical isolation measures

Brazil: proportion of deaths from COVID-19 by ethnicity/race, 10 April 2020-24 July 2020

(Percentages)

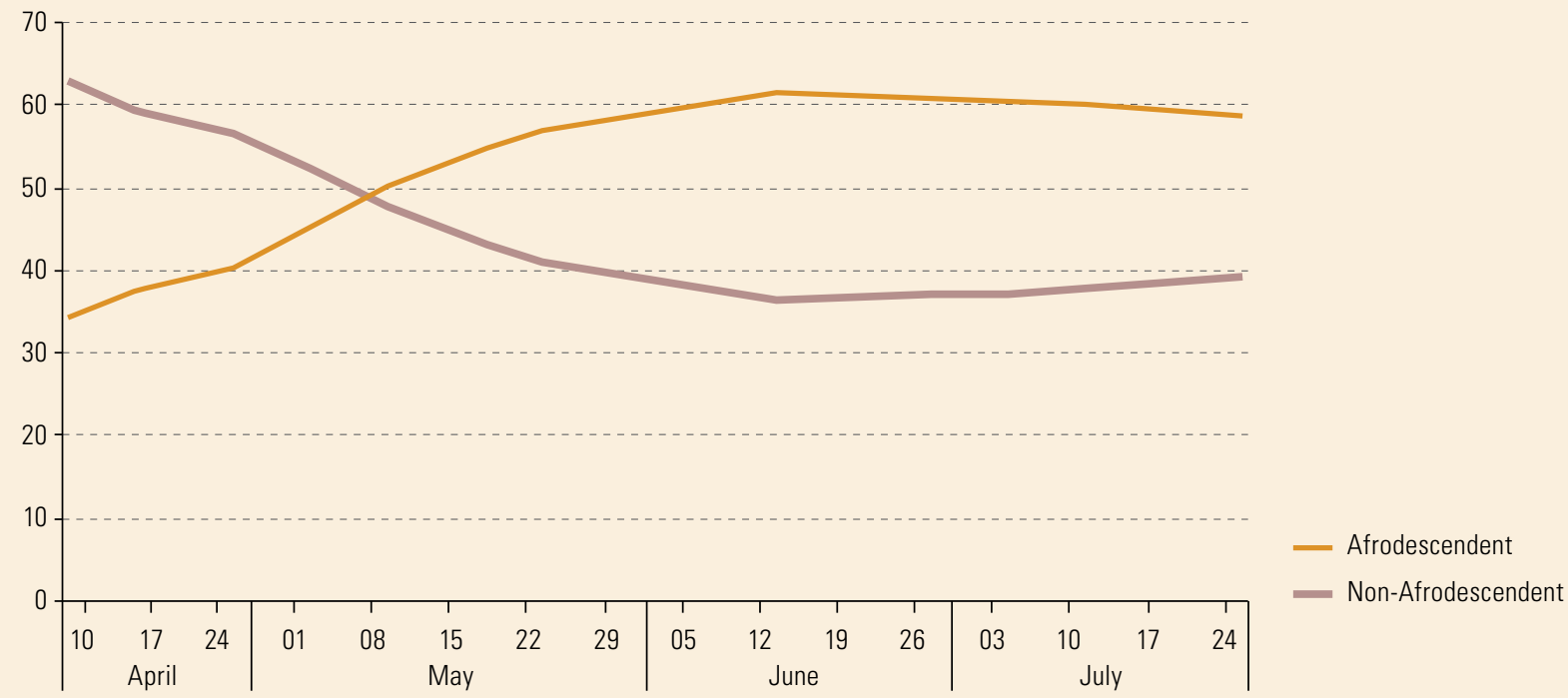

Source: Economic Commission for Latin America and the Caribbean (ECLAC), on the basis of Ministry of Health, Boletín Epidemiológico, several issues [online] http://www.saude.gov.br/boletins-epidemiologicos

Racial and social criteria are major factors in Brazil's COVID-19 mortality and infection rates. Afrodescendants, especially those living in northern and northeastern Brazil, are more likely to become infected and die from coronavirus and they also have more comorbidities. In Brazil, the second highest risk factor for death among hospitalized people is being of African descent (the first risk factor being age). The Afrodescendent population is at $47 \%$ greater risk of death than the non-Afrodescendent population. The combination of the severity of the outbreak, the country's social and ethnic composition and the Government's failure to implement non-pharmaceutical interventions make Brazil a particularly important country in which to study the impact of COVID-19. According to Brazil's National Household Survey (PNAD) on COVID-19, double the percentage of non-Afrodescendent employees were working remotely than Afrodescendants (17.6\% and 9\%, respectively) (IBGE, 2020). A study of nearly 30,000 cases of hospitalization from COVID-19 highlighted the link between education (as a factor of social stratification and access to information) and risk of death. It concluded that an illiterate Afrodescendent patient was 3.8 times more likely to die from COVID-19 than a non-Afrodescendent patient with higher education. Even when comparing people with the same level of education, there were $37 \%$ more deaths, rising to 50\% when comparing people with higher education, suggesting that discrimination and racism were at work. ${ }^{\mathrm{b}}$

The data for Brazil indicate that the virus began by affecting non-Afrodescendants and then went on to affect Afrodescendants. This is because most non-Afrodescendants live in the most affluent neighbourhoods and employ domestic workers living in the most vulnerable neighbourhoods, often in crowded conditions. This group of workers comprises mainly Afrodescendants, which gave rise to a significant line of coronavirus infection from the wealthiest to the most vulnerable neighbourhoods where Afrodescendants are concentrated. This flow of workers through the city reduced the efficacy of physical distancing and helped to spread coronavirus through the most vulnerable neighbourhoods, further victimizing Afrodescendants. Indeed, in many cities mobility did not decrease despite the fact that some people stopped working after receiving emergency cash transfers. ${ }^{c}$ 
While the figures show that proportionally more Afrodescendants than non-Afrodescendants become sick and die in São Paulo city, traditional communities of Afrodescendants whose ancestors were slaves (quilombos) have also been affected. ${ }^{d}$ As of 19 July, there were 136 deaths and 3,465 confirmed cases of COVID-19 in quilombo communities. ${ }^{e}$ The current difficulties they are experiencing in containing the virus are related to their historical conditions: poor access to public health policies, poor infrastructure and lack of regularization. In many cases, this lack of regularization of land ownership prevents quilombo communities from farming their land, forcing some of their members to migrate to the cities in search of work. They also need to leave the community to seek health care and, owing to the lack of testing, they end up returning home without medical guidance or medication and resort to their traditional knowledge to fight the virus. A further problem is poor access to services such as the Internet, electricity and mobile phones, making it difficult for them to complete emergency cash transfer applications.

Source: Ministry of Health of Brazil (2020), "COVID-19 no Brasil" [online] https://susanalitico.saude.gov.br/extensions/covid-19_html/ covid-19_html.html\#/dashboard/; Brazilian Geographical and Statistical Institute (IBGE), "Brasil: indicadores de saúde", 2020 [online] https://COVID-19.ibge.gov.br/pnad-covid/; National Coordination of Quilombo Communities (CONAQ), "Observatorio Covid-19 en Quilombos" [online] https://quilombosemCOVID-19.org/; Brasil de Fato, "Levantamento inédito mostra que 46 quilombolas já morreram por coronavírus no Brasil", 28 May [online] https://www.brasildefato.com.br/2020/05/28/levantamento-ineditomostra-que-46-quilombolas-ja-morrerampor-coronavirus-no-brasil.

a The University of Cambridge and Brazil's Federal University of Espírito Santo (UFES) are conducting a study that considers the epidemiological data of 99,500 Brazilian patients who were screened for certain criteria (race/ethnicity, age, sex, geography, symptoms and comorbidities). This screening exercise led to the analysis of 11,300 hospitalized patients. It was based on the racial categories in the census (white; brown or mixed ethnic ancestry (pardo); black; yellow and indigenous). The data will be updated during the pandemic. See [online] https:// www.medrxiv.org/content/10.1101/2020.05.19.20107094v1.full.pdf.

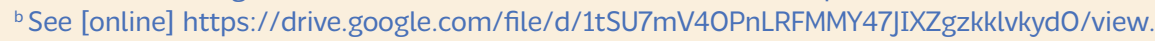

' Law number 13982 of 2 April 2020. See [online] http://www.planalto.gov.br/ccivil_03/_ato2019-2022/2020/lei/l13982.htm.

${ }^{d}$ In April this year, the Brazilian Geographical and Statistical Institute (IBGE) reported that there were 5,972 quilombo communities in 2019. See [online] https://www.brasildefato.com.br/2020/05/28/levantamento-ineditomostra-que-46-quilombolas-ja-morreram-porcoronavirus-no-brasil.

e See [online] https://quilombosemCOVID-19.org/.

In Colombia, as of 6 July 2020, of the 9 municipalities with the largest number of Afrodescendants, 7 ranked among the 10 with the highest number of COVID-19 cases and 6 ranked among those with the most deaths. ${ }^{9}$ Of these nine municipalities, Cali had the most Afrodescendants $(263,257)$ and Barranquilla had the fewest $(58,318)$.

\section{A. Poverty}

Between 2002 and 2014, poverty diminished significantly in Latin America. One of the reasons was a favourable economic environment and a political situation where the eradication of poverty, reduction of inequality and extension of social protection was moved up many countries' agenda. State action was expanded, social investment increased through redistributive policies and progress was made on the path to redressing targeting and recovering universal social policies with a rights-based approach, as opposed to privatized education, health and social protection (ECLAC, 2016a, 2017a, 2017b, 2017c, 2019a and 2019b, cited in ECLAC, 2020b). However, in 2015 this trend began to be reversed against the background of an economic slowdown and fiscal adjustment policies that impacted the continuity of poverty reduction and social inclusion policies (Abramo, Cecchini and Morales, 2019).

The incidence of poverty diverges markedly among different population groups, with many of these gaps reflecting the social inequality matrix in Latin America (ECLAC, 2016a). The incidence of poverty is particularly high among people living in rural areas, children and adolescents, women, indigenous people and the Afrodescendent population (ECLAC 2016b, 2017b, 2017c, 2019a and 2019c). In 2018, the monetary poverty rate among the Afrodescendent population of six countries where household surveys are disaggregated by ethnicity/race exceeded the rate for the non-Afrodescendent population in Brazil, Colombia, Ecuador,

Special processing of census microdatabases using REDATAM and Appendix: Municipalities of Colombia by COVID-19 cases [online] https://es.wikipedia.org/wiki/Anexo:Municipios_de_Colombia_por_casos_de_COVID-19. Cases recorded as of 6 July 2020 . 
Peru and Uruguay (see figure 1). The highest poverty rate among Afrodescendants was in Colombia (40.8\%) and the widest racial/ethnic gap was in Uruguay, a country with one of the lowest poverty rates in the region and where the percentage of Afrodescendants living in poverty was around three times higher than that of non-Afrodescendants. In Brazil and Peru, the percentage was around twice as high. A further finding was a higher incidence of poverty among Afrodescendants in rural areas (except in rural Panama) (ECLAC, 2020b).

Figure 1

Latin America (6 countries): incidence of poverty by ethnicity/race, 2018

(Percentages)

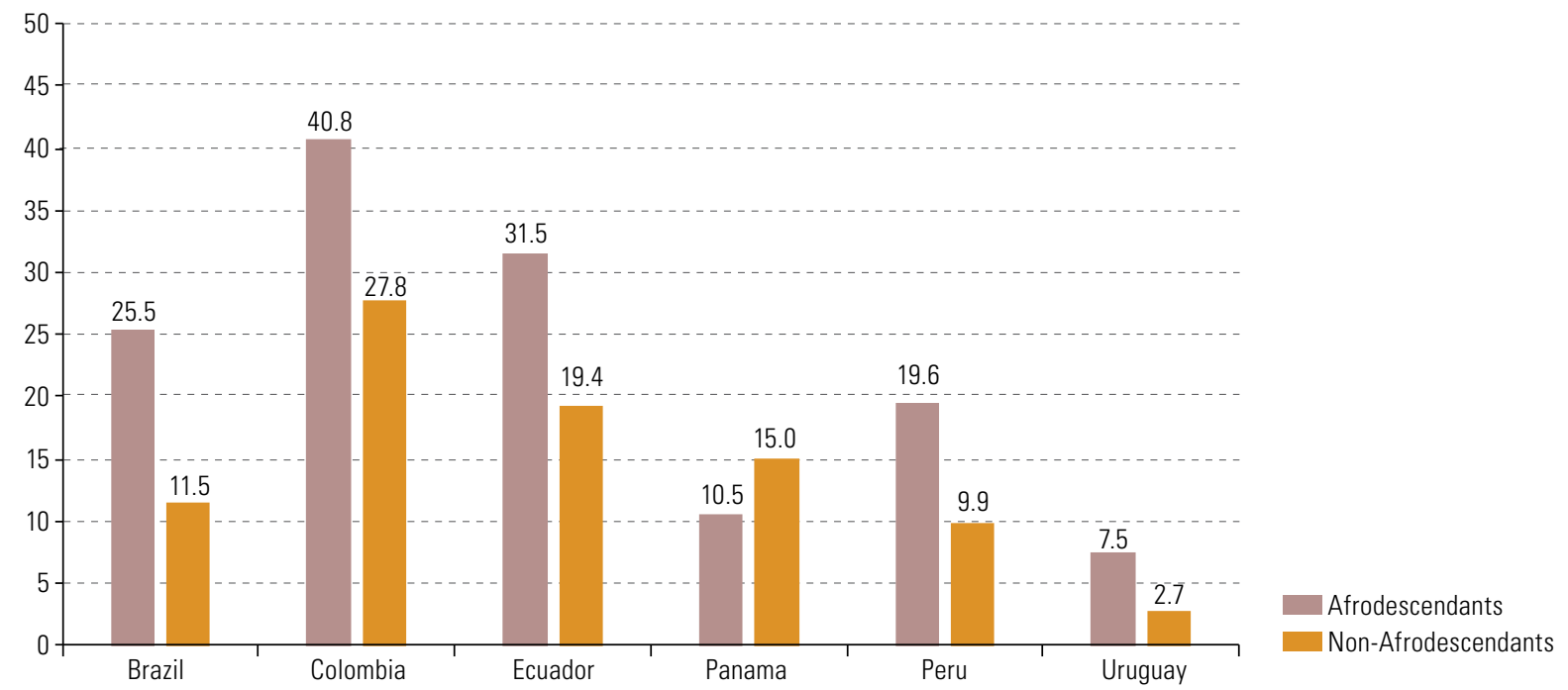

Source: Economic Commission for Latin America and the Caribbean (ECLAC), "Afrodescendientes y la matriz de la desigualdad social en América Latina: retos para la inclusión", Santiago, unpublished, 2020.

Note: The non-Afrodescendent population does not include the population that self-identifies as indigenous, or cases where the ethnicity/race is unknown.

As a result of the COVID-19 pandemic, it is estimated that regional gross domestic product will fall by $9.1 \%$ and that unemployment will rise to $13.5 \%$ by the end of the year. This would have a direct negative impact on household income and make it difficult for households to secure enough resources to meet their basic needs. ECLAC predicts that the number of people living in poverty will increase by 45.4 million, from 185.5 million in 2019 to 230.9 million in 2020, which would represent $37.3 \%$ of the Latin American population. ECLAC also foresees more unequal income distribution in all countries in the region (ECLAC, 2020d).

Therefore, there is no doubt that the COVID-19 pandemic is impacting a population where the proportion of Afrodescendants living in poverty was already higher. The State should therefore cater to them by providing not only the necessary health care and equipment (health personnel, alcohol gel, face masks and other items) but also cash and in-kind transfers to the unemployed, and by expanding and continuing basic services such as water and food deliveries. There is also an urgent need for longer-term policies to lessen the region's glaring income inequalities.

\section{B. Adequate housing and access to services}

All States that have ratified an international treaty on housing or have pledged to protect the right to housing through national legislation have the responsibility to ensure that people have access to adequate housing. ${ }^{10}$ Target 11.1 of the 2030 Agenda is to "by 2030,

10 The following instruments have recognized adequate housing as part of the right to an adequate standard of living: Universal Declaration of Human Rights (1948), Convention relating to the Status of Refugees (1951) Social Policy (Basic Aims and Standards) Convention, 1962 (No. 117); International Convention on the Elimination of All Forms of Racial Discrimination (1965); International Covenant on Economic, Social and Cultural Rights (1966); International Covenant on Civil and Political Rights (1966); Convention on the Elimination of All Forms of Discrimination against Women (1979); Convention on the Rights of the Child (1989); and Convention concerning Indigenous and Tribal Peoples, 1989 (No. 169) of the International Labour Organization (OHCHR, n/d). 
ensure access for all to adequate, safe and affordable housing and basic services, and upgrade slums" (United Nations, 2015). Priority action 77 of the Montevideo Consensus provides the means for overcoming territorial vulnerabilities by enhancing the habitability of housing and access to basic services (ECLAC, 2017a). One of the lines of action in the Regional Agenda for Inclusive Social Development is to reduce territorial inclusion gaps by implementing policies to increase access to basic services and infrastructure, including Internet access (ECLAC, 2020c). The Programme of activities for the implementation of the International Decade for People of African Descent recognizes the poor and insecure housing in which many people of African descendant live and calls on States to develop and implement policies and projects aimed at ensuring that they gain and sustain a safe and secure home and community in which to live in peace and dignity (United Nations, 2014b). Finally, the United Nations Conference on Housing and Sustainable Urban Development (Habitat III), held in Quito (Ecuador) in October 2016, adopted the New Urban Agenda, which sets goals for the next 20 years and seeks to create a mutually reinforcing link between urbanization and development, promoting more inclusive, compact and connected cities through urban planning and design, governance and urban legislation (United Nations, 2017). This will require the adoption of measures targeted specifically at Afrodescendent populations.

Importantly, States are obliged to prevent and remedy homelessness, to provide the necessary infrastructure for housing to be considered adequate, ${ }^{11}$ to guarantee that vulnerable individuals or groups can access it and, lastly, to ensure that non-State actors assume their responsibilities with respect to this right. Despite this, a huge number of people do not have adequate housing and live in overcrowded informal settlements or in dangerous and unsanitary conditions $(\mathrm{OHCHR}, \mathrm{n} / \mathrm{d})$, which facilitates the spread of the new coronavirus.

The right to housing is linked closely with the social inequality matrix and the social determinants of health, as the adequacy of housing depends on household income and Afrodescendants belong to the lowest-income social strata. Moreover, women are hardest hit by the problem of inadequate water and sanitation because they are in more frequent contact with contaminated water and human waste. In Brazil, for example, women self-identifying as indigenous, of brown or mixed ethnic ancestry (pardo) or preto are found to experience the highest rates of inadequate sanitation and the most difficulties in accessing safe water ${ }^{12}$ (24.3\%, 33.0\% and 40.9\%, respectively) (BRK Ambiental/Instituto Trata Brasil, 2018).

\section{Overcrowding}

The health crisis caused by COVID-19 has exposed problems relating to the right to housing in segregated and unequal cities where the real estate market is exclusive and the informal market offers precarious housing conditions characterized by overcrowding, unsafe sanitation and electrical installations, and inflated prices. In situations like these, overcrowding poses a severe threat that prevents physical distancing measures from doing their job of reducing the risk of infection. Cramped dwellings, overcrowding and lack of basic sanitation and water services can increase spread and make staying at home during physical isolation measures synonymous with safety and tranquillity for only a small section of the population, as it is impossible to be safe in camps, slums or dwellings where several family groups live crowded together and there are poor water and sanitation services. Overcrowding is not the only problem hindering the application of physical isolation measures among the most vulnerable sectors of society. Another is the limited presence of the State and the intense personal ties needed to cope with the difficulties of everyday life.

The following data showing more overcrowding among Latin America's Afrodescendent population, coupled with its greater lack of other services, such as water, sanitation and electricity, suggest that Afrodescendants will be one of the groups most affected by the pandemic.

11 Adequate housing is housing that meets the following requirements: legal security of tenure, habitability, accessibility, location and cultural adequacy, as well as sustainable and non-discriminatory access to facilities essential for health, such as safe drinking water, sanitation and washing facilities, means of storing food, refuse disposal, energy for cooking, heating and lighting (OHCHR, n/d).

12 In Brazil, the categories pardo and preto relate to the Afrodescendent category 
Indeed, a previous study based on the 2010 round of censuses showed that, in most countries in the region, the proportion of Afrodescendants living in crowded conditions was higher than that of non-Afrodescendants, in both urban and rural areas (ECLAC, 2017a and 2017b). The countries with the highest percentage of Afrodescendants living in crowded conditions were Colombia, Ecuador, Honduras, Nicaragua and the Plurinational State of Bolivia. In Ecuador, Honduras and the Plurinational State of Bolivia, more than $25 \%$ of the Afrodescendent urban population lived in overcrowded housing. In rural areas, levels of overcrowding were higher: more than $30 \%$ of the Afrodescendent population of Ecuador, Colombia, Honduras, Nicaragua and the Plurinational State of Bolivia lived in crowded conditions.

Figure 2 shows the figures from Mexico's inter-census survey (2015) and the latest censuses from Colombia (2018) and Guatemala (2018). ${ }^{13}$ The situation is most dramatic in Guatemala, where just over one third of the population lives in crowded conditions. Overcrowding is greater in rural areas, especially in Guatemala, but in that country, territorial inequality within racial groups is more striking than racial inequalities, with the percentage of rural dwellers living in crowded conditions as much as twice the percentage of urban dwellers living in crowded conditions, in the case of both Afrodescendants and non-Afrodescendants. Guatemala also has the highest proportion of people living in conditions of critical overcrowding (five or more people per bedroom): 19\% of Afrodescendants and 16\% of non-Afrodescendants (in rural areas, the figures are 30\% and 25\% respectively).

Figure 2

Latin America (3 countries): housing overcrowding by ethnicity/race and place of residence, 2015 and 2018

(Percentages)

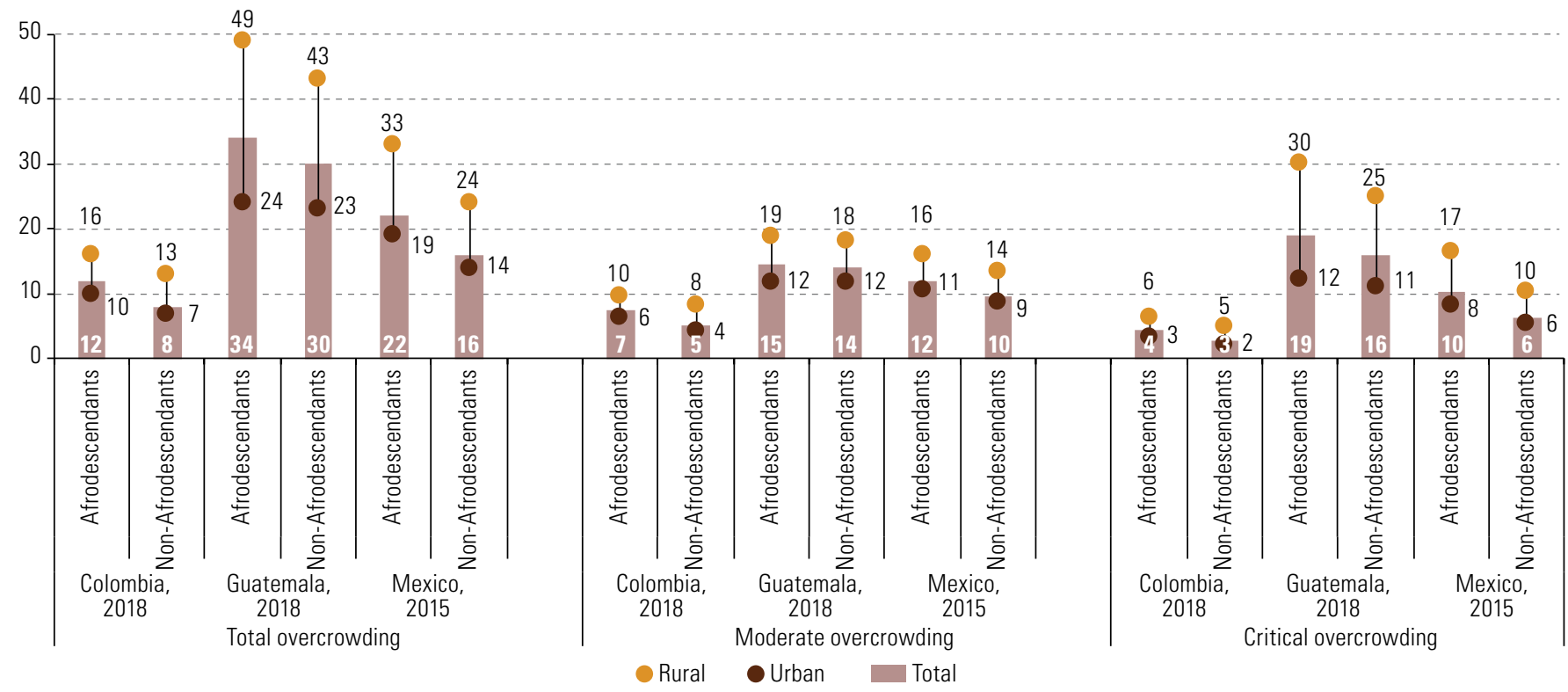

Source: Economic Commission for Latin America and the Caribbean (ECLAC), on the basis of special processing of census microdatabases using REDATAM 7

Note: The non-Afrodescendent population excludes the indigenous population. Overcrowding is considered to be moderate when a bedroom is shared by three or more people. Overcrowding is considered to be critical when a bedroom is shared by five or more people or when there are more than two people but no bedrooms.

The data therefore indicate that, despite living conditions being better in cities than in the countryside, racial inequalities in terms of overcrowding are greatest in urban areas (ECLAC, 2017a and 2017b).

13 This document includes data processed from recent censuses carried out by four countries: Colombia (2018), Guatemala (2018), Mexico (2015) and Peru (2017). As the calculation of indicators relies on the availability of information from the aforesaid censuses, it was not always possible to calculate all the indicators for all the countries. 
The situation described above helps to explain why it is more difficult to prevent the spread of infection among Afrodescendants in the region, who are predominantly urban dwellers. Physical isolation becomes more challenging, not only because of overcrowding but also because of residential density, which is often higher in informal settlements where entire families, which often live under the same roof (especially in the case of migrants), are forced to endure crowded conditions with insufficient public space. This facilitates the spread of COVID-19, especially when the public authorities do not offer sufficient residential facilities where people diagnosed with the disease who are unable to quarantine themselves effectively at home (because they do not have adequate conditions in their homes or are not residents of the city where they were diagnosed, for example) can stay for the duration of their quarantine period.

A final point of note is the problem that older persons face in isolating themselves in their own homes, not only because they live in overcrowded housing but also because no less than one third of Afrodescendent older persons in countries such as Colombia, Guatemala, Mexico and Peru live with children aged 0-14 years (see figure 3). When children return to school, the risk is set to increase for Afrodescendent older persons. Racial inequality is greatest in Colombia, where the proportion of Afrodescendent older persons living with children aged 0-14 years is approximately twice that of non-Afrodescendants.

Figure 3

Latin America (4 countries): people aged 60 years and over living with children aged 0-14 years

by ethnicity/race, 2015, 2017 and 2018

(Percentages)

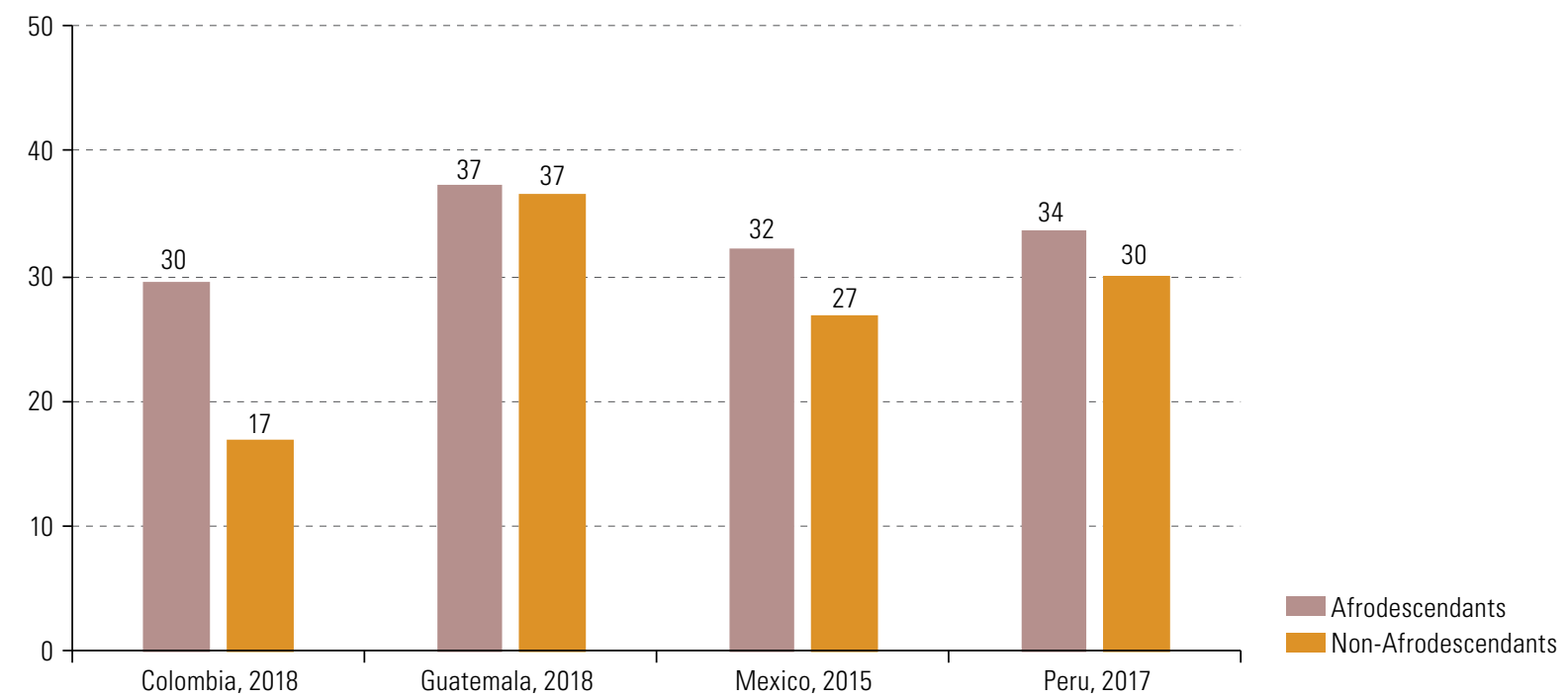

Source: Economic Commission for Latin America and the Caribbean (ECLAC), on the basis of special processing of census microdatabases using REDATAM 7.

Note: The non-Afrodescendent population excludes the indigenous population.

\section{Water}

Another core indicator in these times of pandemic is access to water, which is a component of the right to health and is necessary to meet the need for frequent hand washing, which WHO considers to be one of the most important measures to prevent COVID-19 infection (WHO/UNICEF, 2020). There is a pressing need for sustainable water management to tackle not only the pandemic but also climate change. Deprivation of adequate access to safe water in the region highlights the deep social inequalities that exist, which prevent this right from being realized by the entire population, especially Afrodescendants.

Households without safe water face additional financial costs because poor access to improved water sources leads to health problems, including gastrointestinal disorders, which are a major cause of death in the region, particularly during infancy. Lack of safe 
water diminishes school attendance and performance, not only because it can cause health problems in children but also because it imposes a greater burden of unpaid work on those responsible for collecting it, reducing their time available for study and work. This makes access to improved water sources key to reducing the burden of unpaid work, as it would decrease the time spent collecting it, ${ }^{14}$ a task often performed by women and girls (ECLAC, 2017b).

Previous ECLAC studies based on population censuses of 12 Latin American countries showed that there were deep inequalities between Afrodescendants and non-Afrodescendants in terms of deprivation of adequate access to safe water. The racial/ethnic gap was widest with respect to severe deprivation and in urban areas. In Uruguay, water deprivation among Afrodescendants in urban areas was around three times higher than that of non-Afrodescendants and twice as high in rural areas (ECLAC, 2017a and 2017b)

Mexico's inter-census survey (2015) and the latest censuses from Colombia (2018), Guatemala (2018) and Peru (2017) found very wide inequalities in the indicator of access to safe water, especially in Colombia and Mexico, with Colombia showing the greatest gap (see figure 4). In Colombia, the percentage of Afrodescendants without access to safe water is three times higher than that of non-Afrodescendants and, in Mexico, around twice as high. As regards the territorial dimension, 25\% of Afrodescendants in urban Colombia have no access to safe water, compared with $5 \%$ of non-Afrodescendants. In rural areas, the percentages are $49 \%$ and $35 \%$, respectively.

Figure 4

Latin America (4 countries): population without access to safe water in the home by ethnicity/race and place of residence, 2015, 2017 and 2018

(Percentages)

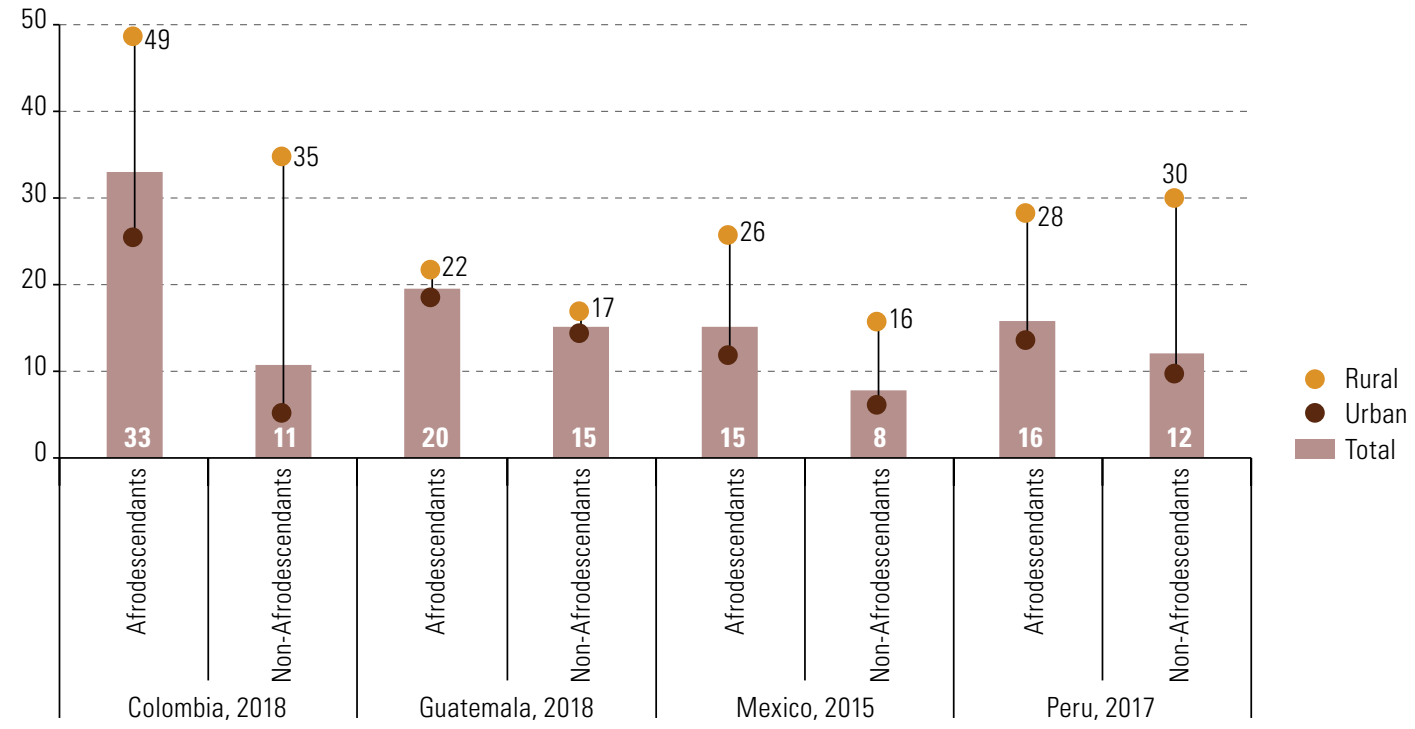

Source: Economic Commission for Latin America and the Caribbean (ECLAC), on the basis of special processing of census microdatabases using REDATAM 7.

Note: The non-Afrodescendent population excludes the indigenous population.

\section{Sanitation}

An adequate waste disposal system is essential for people's immediate health, as well as to prevent environmental pollution from waste seepage into groundwater and contamination of watercourses. WHO points out that, during all infectious disease outbreaks, including the current COVID-19 outbreak, good water, sanitation and hygiene and waste management practices in communities, homes, schools, marketplaces and health-care facilities will help further to prevent human-to-human transmission of COVID-19 (WHO/UNICEF, 2020).

14 An estimated 1.5 hours a day are spent collecting water in the hinterland of Brazil's north-eastern region, a task carried out mainly by women and girls (Campello, 2017) 
An earlier ECLAC study showed that, in most countries, there is a gap between Afrodescendants and non-Afrodescendants in terms of severe deprivation of sanitation services, with Afrodescendants faring worse (ECLAC, 2017a and 2017b). Rural populations in many countries lack adequate waste disposal systems: in Brazil and Cuba, for example, more than $70 \%$ of the rural population suffers severe or moderate deprivation of sanitation services. In most countries, the Afrodescendent population fares worse than the non-Afrodescendent population.

The latest census and inter-census data show that Colombia is the country with the widest gap in this indicator (see figure 5). The proportion of Afrodescendants in Colombia with no access to sanitation services is more than triple that of non-Afrodescendants, highlighting the huge disadvantages suffered by Afrodescendants. In Mexico, the trend is the same and the proportion of Afrodescendants with no access is double that of non-Afrodescendants. Territorial gaps are extremely high among both Afrodescendants and non-Afrodescendants: 68\% of Afrodescendants in rural Guatemala and Peru have no access to sanitation services and the figure is over $30 \%$ in Colombia and Mexico. There are similar territorial gaps among non-Afrodescendants.

Figure 5

Latin America (4 countries): population without access to sanitation in the home by ethnicity/race and place of residence, 2015, 2017 and 2018

(Percentages)

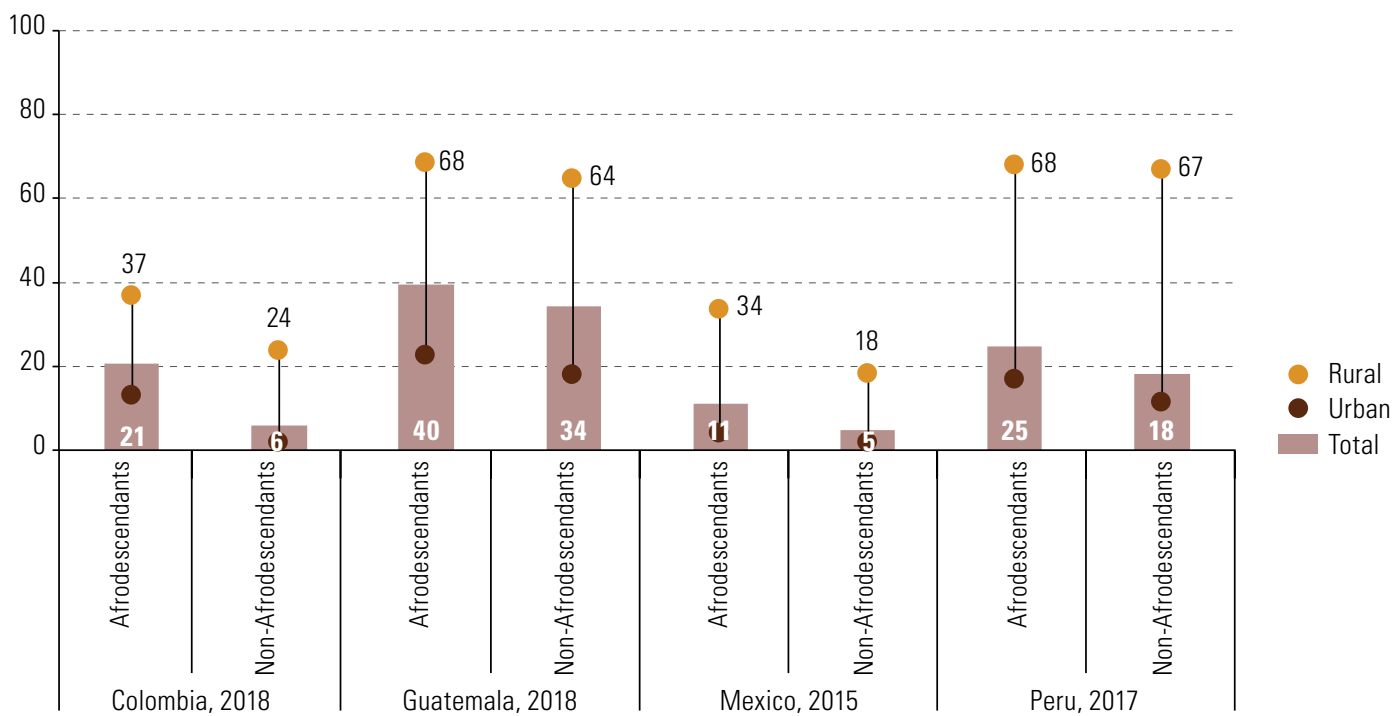

Source: Economic Commission for Latin America and the Caribbean (ECLAC), on the basis of special processing of census microdatabases using REDATAM 7.

Note: The non-Afrodescendent population excludes the indigenous population.

In the context of the social determinants of health and the social inequality matrix, a study on Brazil illustrates how interwoven the factors of gender, race, life cycle and socioeconomic level are. The study showed, among other things, that: lack of treated water affected mainly girls and adolescents (aged 0-14 years), the less educated pardo and indigenous female population and the lower income strata; women who did not receive a regular supply of water were predominantly those aged 20-59 years and Afrodescendent women with lower levels of education and income; poor sewerage systems were commonest among indigenous and Afrodescendent women; and if universal access to sanitation were to be provided, three out of four women who would no longer be deprived of sanitation would be preto (BRK Ambiental/Instituto Trata Brasil, 2018).

As regards COVID-19, the Afrodescendent population's worse situation than the non-Afrodescendent population with respect to the sanitation indicator makes it safe to assume that coronavirus will further exacerbate the conditions of the Afrodescendent population. 


\section{Electric power}

Electric power is key to a country's development and also helps to fulfil other basic human rights: its uses include lighting, cooking, heating, ventilation, refrigeration, preserving food and medicine, security services, telecommunications and industrial plants..$^{15}$ To consider electricity as a human right is to recognize that everyone has the right to well-being and a better quality of life. It would therefore be appropriate to ensure a minimum level of rights that would guarantee access to electricity for the most vulnerable population and communities and for smallholder farmers, including through public subsidies

Electricity is also key to tackling COVID-19, as it enables food to be preserved for longer and powers telecommunications devices, for connecting with others and for education, work and entertainment, among other things. Electricity is therefore critical for compliance with physical isolation measures, as it enables people to leave home less frequently to buy food, study, work and interact with friends and family.

There is nearly universal access to electricity in urban areas of the four countries in the region with recent censuses: Colombia, Guatemala, Mexico and Peru (see figure 6). However, some quite significant territorial and racial inequalities exist with respect to this indicator. In rural Peru, around a quarter of the population has no access to electricity. Mexico is the country with the highest level of access (averaging 97\%) and the one where there are the smallest gaps, while in the other countries there are significant gaps. In the case of Colombia, if the territorial and racial dimensions are considered simultaneously, in rural areas the proportion of Afrodescendants with no access to electricity is double that of non-Afrodescendants (19\% and $8 \%$, respectively) and, in urban areas, more than triple (7\% and 2\%, respectively). The trend is similar in Guatemala: $21 \%$ of rural Afrodescendants lack electricity services, compared with $13 \%$ of their non-Afrodescendent peers. ${ }^{16}$

Figure 6

Latin America (4 countries): population without access to electricity in the home by ethnicity/race and place of residence, 2015, 2017 and 2018

(Percentages)

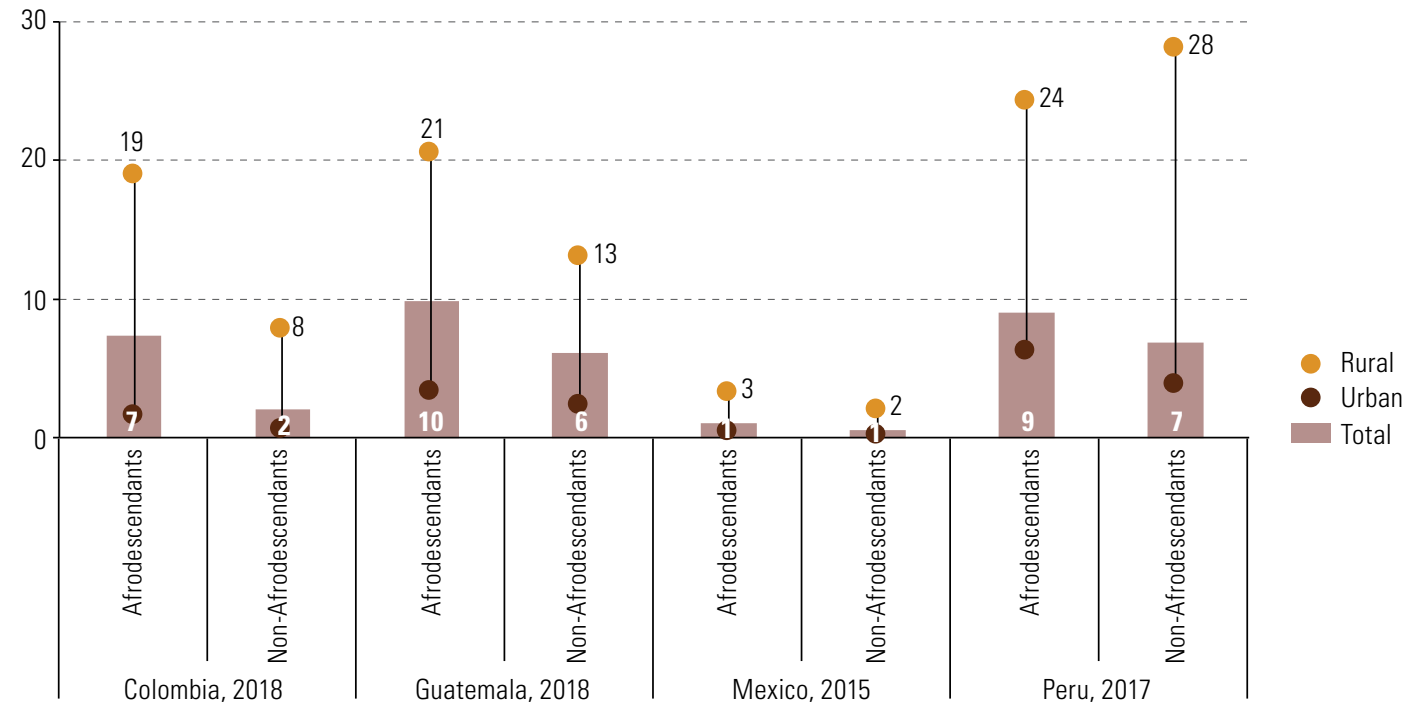

Source: Economic Commission for Latin America and the Caribbean (ECLAC), on the basis of special processing of census microdatabases using REDATAM 7.

Note: The non-Afrodescendent population excludes the indigenous population.

15 The use of wood as fuel represents a significant opportunity cost, especially for women who are responsible for collecting it, in terms of the time they could spend on other activities, such as paid work, and the potential repercussions of handling the heavy weights involved and the often long distances travelled to collect and transport wood (ECLAC, 2017b)

16 A study conducted by ECLAC on the basis of household surveys also found a very wide racial gap in rural Uruguay, where there was a 10 percentage point difference in access to electricity between Afrodescendants and non-Afrodescendants ( $87.5 \%$ and $97 \%$, respectively) (ECLAC, 2020b) 
Despite increased coverage of electricity services, the COVID-19 crisis is bound to affect the payment of electricity bills because of a drop in the income of the most vulnerable population. This makes it crucially important for Governments to intervene in the electricity market to prevent the most vulnerable groups from being deprived of electricity because they cannot pay their bills. The need to ensure universal coverage of electricity services should also be considered.

\section{Internet}

Access to new technology is becoming increasingly vital in enabling countries to develop in a variety of areas, from education, culture and entertainment to productive and labour market activities. Over the past two decades, the region has made progress in increasing coverage of and access to digital devices, especially mobile phones (which have enabled a large number of people to access the Internet). However, there are significant gaps in access to this service, both between countries and between urban and rural areas, with connectivity on average six times greater in urban areas. There are also major gaps according to the socioeconomic level of households and individuals (ECLAC, 2019b, 2019c and 2020b).

In three of the above-mentioned countries, gaps in Internet access in the home are more striking in territorial terms than in ethnicity/race terms (see figure 7). ${ }^{17}$ In rural areas, Internet access in the home is extremely low (under $10 \%$ in all three countries). In urban areas of Colombia, non-Afrodescendants account for the largest proportion of those with Internet access in the home (57\%): around 1.5 times greater than that of their Afrodescendent peers (37\%). The racial gap is also very wide in Peru, where the proportion of non-Afrodescendants with Internet access in the home is also around 1.5 times greater than that of Afrodescendants. The gap is slightly smaller in Guatemala.

Figure 7

Latin America (3 countries): percentage of population with Internet access in the home by ethnicity/race and place of residence, 2017 and 2018

(Percentages)

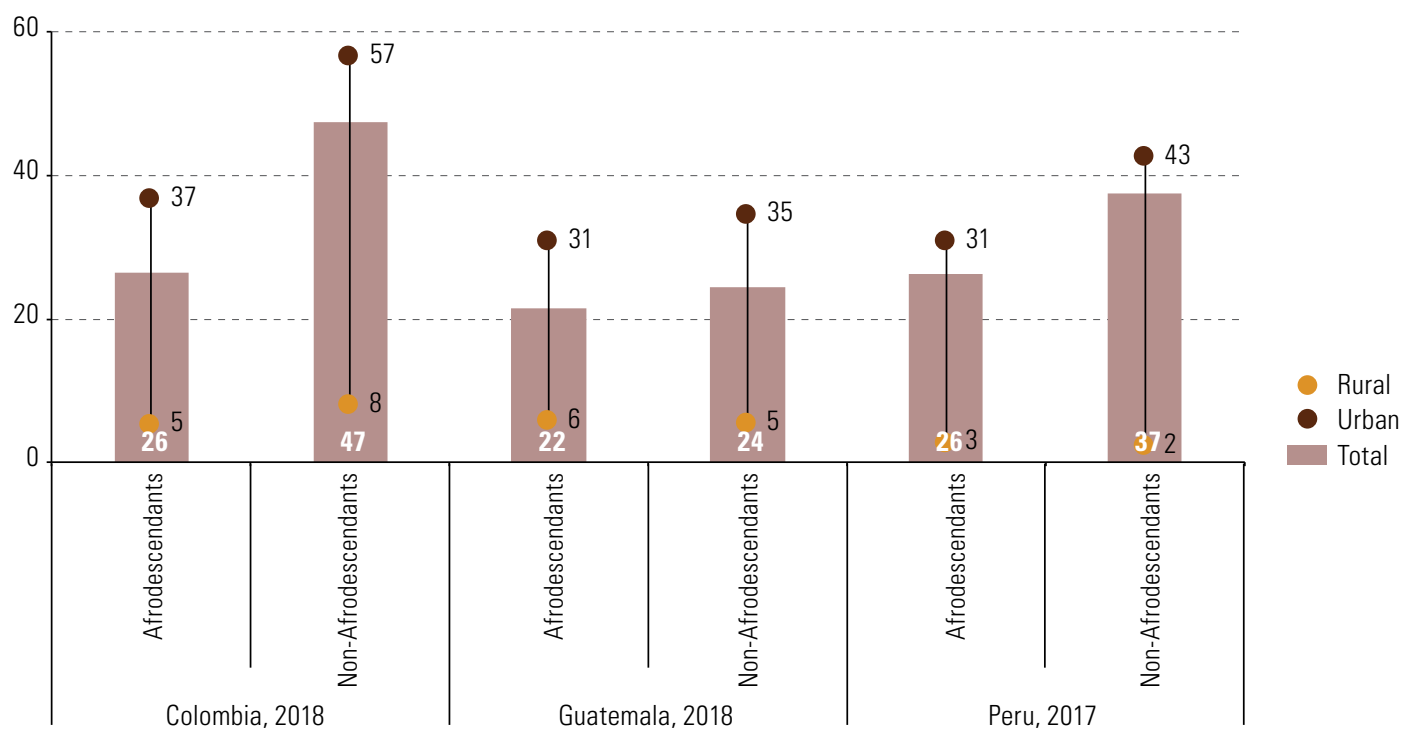

Source: Economic Commission for Latin America and the Caribbean (ECLAC), on the basis of special processing of census microdatabases using REDATAM 7.

Note: The non-Afrodescendent population excludes the indigenous population.

17 In all countries, respondents were asked whether the dwelling or household had an Internet connection or service. Colombia was the only country to indicate that the Internet connection could be fixed or mobile. 
Access to the Internet in the home is becoming more and more key, especially as COVID-19 spreads and it becomes more necessary to adopt isolation and physical distancing measures, with their heavy impact on work, recreation and education. As regards education, since the earliest weeks of the pandemic, school and university agendas have been fulfilled through classes and assignments via Internet. In the world of work, teleworking has already become a reality for some workers and is expected to grow after the pandemic is over. Internet access is key not only to enabling continuing delivery of and access to health services but also to enabling people to continue to socialize, which is very important for their mental health. As the need for Internet access in the home is becoming so pressing, countries should make headway in implementing policies to increase coverage and eradicate territorial, socioeconomic and ethnic/racial inequalities.

An ECLAC study mentioned earlier, which had been based on recent household surveys disaggregated by ethnicity/race, concluded that Uruguay was the only country where more than half the Afrodescendent population had Internet access in the home (52\%) but, even there, the proportion was considerably lower than that of the non-Afrodescendent population (70\%) (ECLAC, 2020b). In the other countries analysed in this study (Brazil, Colombia and Ecuador), the proportion of Afrodescendants with Internet access was approximately $25 \%$ to $50 \%$ lower than that of non-Afrodescendants, with no significant differences in access between men and women (ECLAC, 2020b).

\section{Education}

Primary education is almost universal in Latin America, and the percentage of young people attending secondary school has increased significantly, although secondary school completion remains a challenge. However, among Afrodescendants, there tends to be a higher level of early school leaving and students falling behind the normal grade level for their age, as they are required to work from an early age to alleviate family economic difficulties. The numbers of young people with access to university or non-university post-secondary education vary widely. Among young people aged 20-29 years, the proportion of Afrodescendants who attain higher education (at university or non-university level) ranges from 8.5\% in Uruguay to $38.3 \%$ in Cuba. Uruguay, Brazil and Ecuador are the countries with the biggest racial gap. In Uruguay, the proportion of young non-Afrodescendants accessing higher education is three times higher than that of Afrodescendants: 27.8\% compared with just 8.5\%. In Argentina, Honduras, Nicaragua and Panama, the situation also appears to be more favourable for non-Afrodescendants, although their gaps are smaller (ECLAC, 2017a and 2017b).

Unequal access to education and gaps in learning and quality of education in turn affect Afrodescendants' labour market situation because education is one of the factors that determine labour force participation and hence the way in which income and well-being are distributed in the region. Education is therefore considered to be one of the determinants of health. Level of education also determines the type of care received at home by children and the family unit.

Another major indicator of exclusion is young people who neither study nor are employed in the labour market. This group's situation in the region is worrying because, despite their heterogeneity, there are signs that such young people are at a disadvantage and at greater risk of falling into - or less likely to exit- poverty. Often young people are also stigmatized as persons at risk. Around half this population belongs to the bottom two income quintiles and comprises largely women living in urban areas, many of whom already have children. These young women undertake much of the unpaid work in the home and find it difficult to continue or complete their studies and to enter the labour market because of inadequate care systems and lack of policies for combining study, work and personal and family life (ECLAC, 2014 and 2018b).

In the COVID-19 context, people's prior educational attainment will give rise to inequalities in the ability of households to comply with the protocols recommended by the health authorities and to support school children in carrying out class activities remotely. Having minimum conditions in the home to complete educational activities will also have an impact (for instance, someone with the time available and sufficient capacity to support youngsters). During a lockdown, to ensure that educational activities can be carried out, 
it is also essential to have computers, good Internet connections and adequate physical space to complete the activities, in addition to a good home environment (one free from harassment and domestic violence). The outlook for the region suggests that early school leaving is highly likely to increase because of school closures, which are expected to impact more heavily on young people from vulnerable households, especially those of African descent.

\section{Employment and income}

In Latin American societies, work is key in enabling people to position themselves in the social structure and to achieve well-being and improved health. An individual's socioeconomic stratum is one of the main determinants of health and one of the elements that structure the social inequality matrix. Standing in a given socioeconomic stratum is determined by the production structure and the positions occupied by individuals or their families over time. This depends chiefly on how ownership is structured and how society's productive and financial resources are distributed. The labour market plays a key role in this, as labour income accounts for an average $72 \%$ of total household income in the region (ECLAC, 2017a, 2017b and 2019c).

According to ECLAC, education and work are the main ways of achieving social and labour market inclusion and enjoying well-being. In the region, secondary education is considered to be a minimum for increasing productivity and mitigating the intergenerational reproduction of poverty, inequality and exclusion, even though educational achievements are not automatically transferred to the labour market in terms of employment or income. Not only is work a determining factor for poverty reduction, social and economic integration, equality and access to social protection, it is also key to building personal autonomy, identity and dignity and to expanding citizenship. However, work is also where there is a great deal of discrimination on grounds not only of race but also of gender, age, disability, immigration status, sexual orientation and gender identity (ECLAC, 2010a, 2012a, 2012b, 2012c, 2016a, 2016b and 2016c).

Certain labour market indicators have a decisive impact on people's health. Being unemployed, having insufficient income, working in the informal market or having no unemployment insurance or pension affects the access of individuals and their families to health in various ways, while also increasing demands on social protection systems.

In Latin America, unemployment affects indigenous and Afrodescendent people to a greater extent, especially young people and women in these groups (Guimarães, 1999; Del Popolo and Rangel, 2011; ECLAC, 2013a, 2016a and 2016d). Also, a higher level of education does not necessarily translate into a higher level of employment or less racial, gender or age inequality in the labour market (ECLAC, 2016a, 2017a, 2017b, 2018a and 2018b). In 2016, the unemployment rate among Afrodescendants was approximately twice that of non-Afrodescendants in Ecuador, around 50\% higher in Panama and more than 30\% higher in Uruguay. With regard to sex, in these same countries, unemployment affected Afrodescendent women to a greater extent (Abramo, Milosavljevic and Rangel, 2019).

Finally, income also reflects serious discrimination on race, sex and other grounds. Women's wages remained significantly lower than men's, despite their having attained a higher level of education (ECLAC, 2010b, 2012c, 2016a and 2016e). Similarly, the wages earned by Afrodescendants, as well as their achievements in both education and the labour market, continued to be lower than those of non-Afrodescendants (Taschdjian and Vásquez, 2011; Telles and Steele, 2012; ECLAC, 2016a, 2017a and 2017b). In Brazil in 2016, the hourly income of Afrodescendants was approximately $55 \%$ less than that of non-Afrodescendants, in Peru and Uruguay it was around 25\% and, in Ecuador, around 15\%. With regard to sex, non-Afrodescendent men fared the best and Afrodescendent women, the worst. When controlling for level of education, the gap was even more marked among people with tertiary education, with Afrodescendent women earning around $60 \%$ of the income of non-Afrodescendent men (Abramo, Milosavljevic and Rangel, 2019).

The COVID-19 pandemic has struck the region at a time of great economic weakness. Over the 2010-2019 period, regional gross domestic product grew by only $0.4 \%$ (the 
lowest growth rate since the 1950s). The pandemic is therefore expected to trigger the region's greatest economic and social crisis in decades and, as already mentioned, it will have a highly negative impact on employment, poverty and inequality (ECLAC, 2020d).

According to estimates by the International Labour Organization (ILO), 31 million full-time jobs could be lost (assuming a 40-hour working week) and, coupled with an increase in unemployment, informal employment is expected to rise still further from its current rate of around 54\%. Informal workers lack access to quality health services and the nature of their work puts them at greater risk of infection. Moreover, low incomes limit their ability to save to tide them over prolonged periods of inactivity. They also lack unemployment insurance (ECLAC/ILO, 2020).

In view of the enormous ethnic and racial inequality that exists in the region, the situation is expected to be even more dramatic for Afrodescendent populations, especially those living in city suburbs, slums and rural communities. In such areas, there is a higher incidence of poverty and poorer sanitary conditions as a result of overcrowding and insufficient safe water, sanitation and health services. In addition, unemployment will rise and income will fall in these areas.

Physical isolation measures have also triggered a debate on the heavy burden of unpaid domestic and care work undertaken mainly by women in a context of unequal sexual division of labour, while drawing attention to the indispensability and invisibility of this type of work with respect to market relations. In times of pandemic, the burden of domestic work is exacerbated by the extra activities required to eliminate the virus in the home. This falls not only on women who go out to work (in medical care, essential services and paid domestic work) but also on women working from home who have to balance teleworking with caring for children not attending school and on women domestic service workers who perform this type of work in their employer's home. The death of a 62-year-old domestic worker in Rio de Janeiro on 17 March 2020 (the city's first confirmed death from COVID-19) illustrates this tragic social reality. According to IBGE (cited in Duarte, 2020), more than $70 \%$ of Brazilian female domestic workers are in the informal sector. In this connection, Brazil's National Federation of Domestic Workers (FENATRAD) issued an official request ${ }^{18}$ for a review of Decree number 729 of 5 May 2020 by the Governor of the state of Pará instituting physical isolation measures in the capital and in a further nine cities in the state. ${ }^{19}$ The decree considered domestic services as an essential activity. FENATRAD believes that the measure is based on a slavery rationale and calls for domestic workers to be excused from turning up to work and to be paid a guaranteed salary, except in the case of workers caring for older persons living alone or persons requiring constant assistance, or in the case of workers providing services to the dependants of key workers engaged in designated essential activities (Duarte, 2020).

Domestic work has never been more visible under the capitalist system. Its status as a woman's job should be demystified and its importance recognized in the emancipation of all women, without distinction of class or ethnicity/race. In many countries in the region, Afrodescendent women perform most of the paid care work in other people's homes, on top of unpaid care work in their own homes.

\section{Actions to combat COVID-1920}

In order to mitigate the impact of the pandemic, national Governments in the region have implemented policies targeted at the most vulnerable population, especially emergency cash transfers. These policies also benefit the Afrodescendent population because, in most Latin American countries, it is overrepresented in the most vulnerable sector of the population. However, not many countries have implemented policies targeting

18 See [online] https://fenatrad.org.br/2020/05/08/fenatrad-protesta-contra-decreto-no-para-que-determinaa-atividade-domestica-como-servico-essencial-durante-a-pandemia-da-covid-19/

19 FENATRAD is a trade union organization founded in 1997 and affiliated to the Unified Workers' Central of Brazil (CUT), Brazil's National Confederation of Commercial and Service Workers (CONTRACS), the Latin American and Caribbean Confederation of Domestic Workers (CONLACTRAHO) and the International Domestic Workers Federation (IDWF)

20 This section was written with input from the Afrodescendent Institute for Study, Research and Development See [online] https://afrodescendientes.org/sitio-instituto/. 
the Afrodescendent population specifically and, in several cases, it is the communities themselves that have organized to battle against COVID-19. Most of these actions focus on the provision of food, shelter and hygiene products, not only for cleaning the home but also diapers for children and older persons and women's sanitary products. The actions have been conducted in a variety of ways: requesting in-kind donations, opening bank accounts to raise funds, and food collection campaigns carried out by the organizations themselves or in coordination with other networks.

However, a number of countries have implemented specific policies for the Afrodescendent population in the context of COVID-19. In March, Colombia's Ministry of Health and Social Protection issued recommendations targeted at ethnic groups, including Afrodescendants. The document recognized that the Afrodescendent population was impacted more heavily because of the social determinants of health, making it more vulnerable to coronavirus. It stated that this made it necessary to define specific guidelines to guarantee the full right to health, especially in a public health emergency. To this end, it proposed preventive measures to tackle coronavirus in accordance with the universal principle of self-determination. It stated that ethnic communities should adopt and adapt existing and future general preventive measures to take into account each community's sociocultural characteristics. The document also recommended that communities: take measures to prevent people from leaving their area; limit the entry of people from outside their communities; restrict community activities and large-scale events; isolate people with symptoms; identify suspected cases promptly and define actors and routes for immediate notification and reporting; implement communication actions targeted at the entire community according to its world view, customs and practices; and adopt special protection measures for the community's older persons, among other recommendations. The document provided guidance on preventing infection, including: defining routes for delivering food and supplies by designating people to carry out these tasks; implementing measures to clean and disinfect the community environment; and limiting visits to the home by outsiders. It also provided guidance for when a person exhibited symptoms. Lastly, it made recommendations to health system actors (Ministry of Health of Colombia, 2020a).

In April, the Ministry of Health of Costa Rica published recommendations on preventing COVID-19 in the Afrodescendent population (Ministry of Health of Costa Rica, 2020). The document acknowledged this population's historical vulnerability and recommended that; local emergency committees take into consideration the sociocultural aspects of the Afrodescendent community; the main prevention and information messages be translated into regional English; the principle of equality and non-discrimination be ensured in prevention and mitigation actions, taking into account ethnic, cultural and linguistic diversity; and gender and intersectionality perspectives be included. It recommended avoiding family gatherings and social activities involving more than two people and keeping no less than 1.8 metres away from the general population. It advised that people could continue drinking ancestral herbal teas and taking their usual medication. While the document prohibited funeral rites in accordance with the deceased's traditions, in June, the Ministry of Health published guidelines on the handling, transfer and final disposal of corpses. The document mentioned the principles of human dignity to be applied when handling corpses, principles that should be observed at all times, respecting the beliefs and cosmogony of ethnic communities and always in consultation with community authorities (Ministry of Health of Costa Rica, 2020).

In May, the Government of Mexico published a guide for the care of indigenous and Afro-Mexican peoples and communities in response to the health emergency caused by the SARS-CoV-2 virus (COVID-19). The guide recognized that, as Afro-Mexican peoples had a higher likelihood of experiencing complications from COVID-19 because of their social and economic situation, it was desirable to adopt culturally relevant measures to mitigate the historical gap in health care, as well as their problems in accessing information and the health and economic consequences that these communities have suffered and would suffer. The guide listed 10 points, including; translation, dissemination and implementation of culturally relevant measures; respect for self-determination and autonomy; transfers; care of suspected cases; care of the deceased; and economic and social recovery strategies. It also emphasized that: dialogue would be favoured to reach agreements and decisions for 
implementation; the culture of the deceased would be respected, in line with health measures, and respect for persons who had lost a loved one would prevail; action would be taken to prevent discrimination and avoid stigmatization of deceased persons and their milieu; and preferential attention would be paid to the most vulnerable sectors of the population.

In early May, the Ministry of Culture of Peru began to reinforce preventive messages about coronavirus through radio announcements, animated videos and digital posters offering basic advice on how to prevent COVID-19. The messages were targeted at the 10 regions with the highest concentration of Afro-Peruvians, in accordance with the 2017 population census by the National Institute of Statistics and Informatics (INEI) ${ }^{21}$ They also reminded the Afro-Peruvian population that it was prone to chronic diseases, making it more vulnerable to COVID-19.22 The message content was prepared with the involvement and input of the leaders of the Working Group with the Afro-Peruvian Population (GTPA). The Ministry of Culture had already delivered thousands of face masks to the Afro-Peruvian population of Lima and Callao province and masks for community use had been distributed to representatives of dozens of Afro-Peruvian organizations) (Ministry of Culture of Peru, 2015). Finally, in late May, the Government published guidelines for incorporating the ethnic variable into the administrative records of public entities, in the context of the health emergency declared for COVID-19 (Government of Peru, 2020), to allow morbidity and mortality from COVID-19 to be studied, as well as to enable access to subsidies and other mitigation measures and to facilitate mainstreaming of the ethnic approach into information systems in general.

Seizing the opportunity provided by the pandemic, the Office of the Ombudsperson of Peru made a number of recommendations for the State to consider vulnerable groups, including Afro-Peruvians. The recommendations called for: those promoting or inciting discrimination to be punished; health records to include the ethnicity/race variable to enable data to be obtained on confirmed cases, hospitalizations and deaths from COVID-19, as well as on the presence of pre-existing diseases at the time of care (data that should also be disaggregated by gender and age); measures to be adopted to ensure that the Afrodescendent population has access to, remains in and completes basic education and that full undergraduate scholarships are awarded; Afrodescendants working in the informal market to be protected through financial compensation for the duration of the state of emergency; labour inspections to duly sanction non-compliance with standards undermining workers' rights; and the use of racial profiling to be ruled out as a basis for detaining, intervening with or checking the identity of Afrodescendants (Office of the Ombudsperson, 2020).

The Governments of Honduras and Ecuador, in conjunction with the United Nations, have developed a COVID-19 Humanitarian Response Plan for those countries. The plan considers the Afrodescendent population to be vulnerable to this health crisis and makes explicit reference to it. In the case of Honduras, the plan envisages: supporting the supply of food to women's shelters and to Afro-Honduran women; providing technical assistance to Afro-Honduran women's organizations to enable them to prepare proposals for mitigating the impact of the pandemic; and supplying and distributing hygiene and dignity kits to the Afro-Honduran population affected by COVID-19 (United Nations, 2020a). In the case of Ecuador, the plan's objectives are to: execute the communication plan with special emphasis on Afrodescendent peoples; support the implementation of teaching practices during the closure of schools and early childhood development centres to reach out to the most vulnerable children and adolescents, including Afro-Ecuadorians; promote the economic autonomy of associational groups of women, families with female heads of household and vulnerable groups, such as the Afrodescendent population, and promote the participation and inclusion of these groups in local decision-making, building on their culture and ancestral knowledge by using business models that provide economic and environmental sustainability (United Nations, 2020b).

21 The 10 regions with the highest concentration of Afro-Peruvians were: Tumbes, Piura, Lambayeque, Cajamarca, San Martín, La Libertad, Lima-Callao, Ica, Arequipa and Tacna.

22 According to a specialized study of the Afro-Peruvian population by the Ministry of Culture and the Group for the Analysis of Development (GRADE) (2015), the most recurrent chronic diseases among Afro-Peruvians are high blood pressure (25\%), diabetes (6\%) and heart disease (6\%) 
In July, Brazil adopted Law no. 14021, ${ }^{23}$ which establishes sanitary and epidemiological surveillance measures to prevent the spread of coronavirus among Afrodescendent and indigenous populations, which are considered vulnerable groups. The measures in the emergency plan include the payment of assistance (a monthly minimum wage per family for the duration of the emergency), universal access to safe water, the distribution of hygiene kits and the visit of multiprofessional health teams trained to deal with COVID-19. The law also provides for the immediate delivery of tests, personal protective equipment, medicines and basic baskets of goods, and for the establishment of sanitary barriers. In respect of quilombo communities, it requires the unified health system (SUS) to register and report colour or race in order to guarantee the identification of all members of quilombo communities who are treated. The law also provides for a specific credit programme for these communities.

Brazil's Oswaldo Cruz Foundation (Fiocruz) issued a public call to finance projects nationwide that would help prevent the spread of COVID-19 among the populations and territories most exposed to the disease and would help to guarantee a minimum subsistence for families experiencing social isolation. ${ }^{24}$ The funding comes from donors supporting actions to combat the pandemic, and participation is open to non-profit civil-society organizations with experience of vulnerable populations. The proposals cover issues such as food security, communication, mental health, assistance to at-risk groups and actions to facilitate compliance with physical distancing and hygiene measures. Fiocruz, together with some civil society organizations, has also launched a COVID-19 prevention campaign in the slums by supplying such items as hygiene kits, posters with guidance on care and videos with experts. As part of the campaign, Fiocruz grants a seal of approval for communication materials produced by community organizations (Fiocruz, 2020). Lastly, Fiocruz launched a campaign supported by several institutions, called "Caring is resisting", to boost support for territories that are home to traditional communities hard hit by COVID-19.25

The hardships endured by people living in poverty and the residents of the most lagging territories (many of which are inhabited chiefly by Afrodescendants) led these groups to focus their efforts and to realize that combating the spread of COVID-19 would rely largely on their actions as a community, either by organizing to tackle the pandemic themselves, or by pressuring the public authorities to protect them. Examples of such actions are described below.

In Brazil's slums, since the start of the pandemic there has been a movement to tackle COVID-19 jointly through such actions as the creation of a web page on coronavirus in slums in the dictionary of slums hosted on Wikipedia. ${ }^{26}$ This web page contains a range of information, including data on funds earmarked for projects to combat coronavirus in the slums, more than 500 news reports about coronavirus, audiovisual material produced by and for the slums (dozens of links to music, stories, interviews, podcasts, tutorials, guidelines, reports and communiqués), analysis and proposals on how to tackle the pandemic, data on collectives in action against coronavirus and panels on coronavirus in the slums. Dozens of slums in various Brazilian states participated in the joint effort, asking for help in the form of money and basic baskets of goods, while promoting their products and services. As regards funding, there are news reports on calls for emergency and support projects from such institutions as the United Nations Children's Fund (UNICEF), the European Union and Fiocruz. There are around 100 articles, academic discussions, research reports, action plans and other documents that include the race issue in the discussion on COVID-19 in the slums. There is also a page dedicated solely to collectives and their actions to alleviate the impact of the COVID-19 pandemic in Brazil's various slums and a page with information on how the money was spent and how goods were used.

23 See [online] https://www.camara.leg.br/propostas-legislativas/2242218

24 Fiocruz is a Brazilian public institution, under the Ministry of Health, whose mission is to produce, disseminate and share knowledge and technologies aimed at strengthening and consolidating the unified health system and contributing to the promotion of health and quality of life for the Brazilian population, in order to reduce social inequalities and promote the country's innovation dynamics, with the defence of the right to health and full citizenship as central values. See [online] https://portal.fiocruz.br/fundacao.

25 See [online] https://wikifavelas.com.br/index.php?title=Coronav\%C3\%ADrus_nas_favelas\#Not.C3.ADcias_ sobre_Coronav.C3.ADrus_nas_favelas.

26 See [online] https://wikifavelas.com.br/index.php?title=Coronav\%C3\%ADrus_nas_favelas\#Not.C3.ADcias_ sobre_Coronav.C3.ADrus_nas_favelas. 
The Paraisópolis slum, in the city of São Paulo, which has more than 70,000 inhabitants and a population density of 61,000 people per square kilometre, is a good example of the crucial role of community work in tackling the pandemic in poor neighbourhoods (see box 2). In the Paraisópolis slum, the pandemic has been kept under better control than in other vulnerable neighbourhoods in the city. As of 18 May, its COVID-19 mortality rate was 21.7 deaths per 100,000 inhabitants, compared with a municipal average of 56.2 .

Box 2

Brazil: successful community strategies against COVID-19

As soon as the first case of COVID-19 was confirmed in São Paulo in March, the Paraisópolis slum community designed strategies to address public policy gaps in tackling the disease. It created a system of "street chairpersons", where one person from each street was in charge of monitoring and providing guidance on symptoms of the disease, distributing basic baskets of goods and countering the dissemination of misinformation. The community also hired ambulances and recruited doctors and nurses to provide round-the-clock care. A further 240 residents were trained to support the 60 emergency bases that were established in the slum, attended by firefighters. The local residents' committee also asked the state government for two public schools to be used as isolation centres for sick people. The mortality rate in the Paraisópolis slum is approximately half the municipal average, demonstrating that actions like these can improve indicators. ${ }^{2}$

Further actions have included the production of face masks in some communities in Rio de Janeiro (Oglobo, 2020), São Paulo (UNAS, 2020) and elsewhere. In Rio de Janeirơs Heliópolis slum, 64 seamstresses are making 3,000 cloth masks per day. This project involved a number of civil society organizations and banks in an operation designed to provide masks to health institutions and vulnerable communities.

Paraisópolis, São Paulo (Brazil)
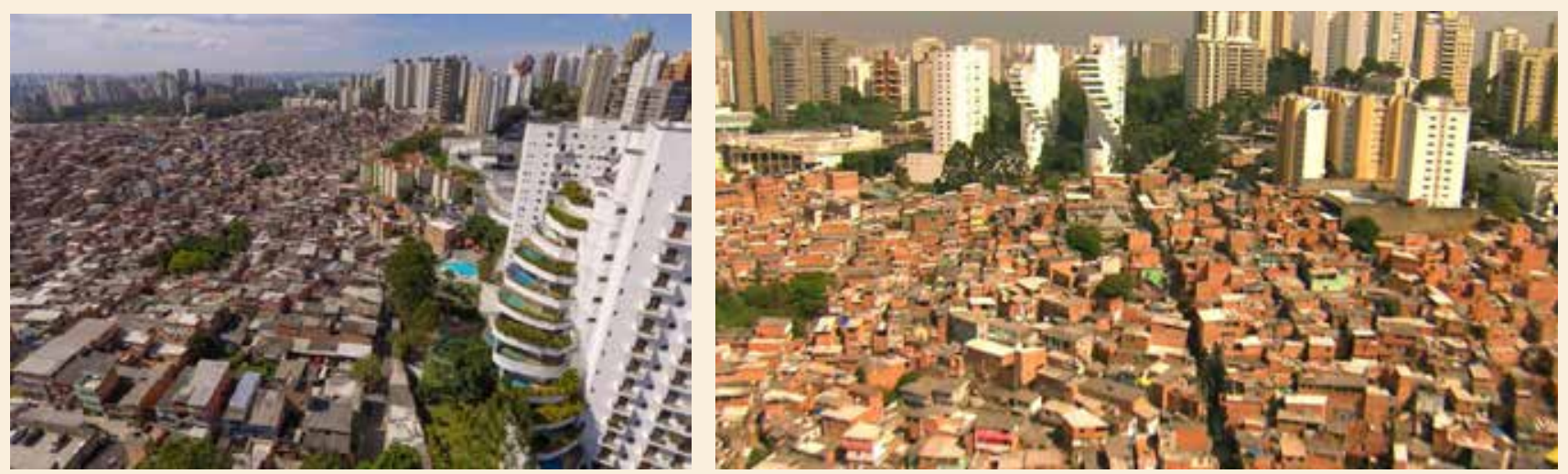

Source: Oglobo, "Costureiras fazem mutirão para produzir máscaras no combate ao novo coronavírus", 2020 [online] https://oglobo.globo. $\mathrm{com} /$ rio/mutirao-de-costureiras-produz-mascaras-de-pano-para-moradores-de-favelas-do-rio-24370006 and União de Núcleos, Associações dos Moradores de Heliópolis e Região (UNAS), "Costureiras de Heliópolis irão produzir máscaras de proteção ao Covid-19", 2020 [online] https://www.unas.org.br/single-post/Costureiras-de-Heliopolis-irao-produzir-mascaras-de-protecao-a-COVID-19.

a See [online] https://noticias.uol.com.br/ultimas-noticias/agencia-brasil/2020/06/25/territorio-precario-controla-covid-19-melhor-quea-media-de-sao-paulo.htm].

In Colombia, in March, the National Conference of Afro-Colombian Organizations (CNOA) published, on its website, guidelines on how to respond to COVID-19, on the grounds that racism also had an impact on the pandemic and that there had been no differential approach in the Government's response. Indeed, the Afrodescendent population is at high risk and, in predominantly Afrodescendent territories, there is no network of equipment and personnel to provide proper care for anyone who might be affected by the disease. CNOA makes recommendations on how to avoid becoming infected, including through frequent hand washing, hygiene measures (respiratory, personal, in the home and workplace and for frequently used objects), physical distancing and wearing face masks. Apart from these individual, household and community recommendations, it also makes recommendations regarding the work that organizations should do to ensure that, in their capacity as ethnic/ territorial authorities, they increase the level of pandemic preparedness, warning and 
response. The recommended measures include: designing action plans, in coordination with territorial and national health authorities, to prevent or reduce transmission, which include hunger prevention and humanitarian aid; setting up a support network; adopting communication measures; boosting traditional medicine; restricting visits by family members, friends and other people transiting through communities; and preventing social stigmatization. ${ }^{27}$

In countries such as Peru, Chile, Panama and Argentina, Afrodescendent organizations have worked to forge linkages with a number of government entities, including the Ministry of Culture of Peru, the Afrodescendent Municipal Office in Arica municipality (Chile) and the Mayor's Office of Panama City, to administer and deliver basic food baskets to Afrodescendent families as humanitarian aid. In Rivera, a department in northern Uruguay, goods have been targeted specifically at Afrodescendent individuals and families previously selected by local organizations or organizations known to the community. A model is being implemented to support trade in the neighbourhoods through the purchase of basic baskets of goods collected by selected families in their areas, as well as to deliver coats to families in their neighbourhoods and to prisoners.

In Nicaragua, Afrodescendent organizations have provided essential support by delivering food kits and basic medical supplies, conducting radio campaigns on local stations (in the native languages of the Afrodescendent population), raising awareness about the care and precautions required to prevent infection, and providing updated information on the spread of COVID-19 in the country.

In Ecuador, alternatives were created to support Afrodescendants who were receiving no income because they had been engaged in informal work. A number of organizations have made arrangements with international cooperation agencies and with the Ministry of Economic and Social Inclusion, as well as with municipal administrations and provincial councils, to deliver hygiene supplies, health services and staple foods, especially to the country's most affected populations. Activities are also carried out with mothers and children to support households, and kits containing books and hygiene supplies are provided.

Finally, a series of virtual activities has been conducted throughout the region to highlight, analyse and reflect on the impact of the pandemic on Latin America's Afrodescendent populations. Some of these virtual actions have focused on providing medical and social support, together with cultural dialogue to promote the health of Afrodescendent populations, especially young people and women. In conclusion, the actions described above and others that have been carried out at local level throughout the region, are targeted solidarity actions instigated by civil society in response to the absence of targeted government policies.

\section{Recommendations}

The pandemic and the ensuing health emergency forced the application of physical isolation policies that disrupted economic activities on a scale unprecedented in history. The United Nations has proposed a framework for the COVID-19 response and a pathway to the new normal, which addresses five priority areas of work: (i) ensuring that essential health services are still available and protecting health systems; (ii) helping people cope with adversity, through social protection and basic services; (iii) protecting jobs, supporting small and medium-sized enterprises and informal sector workers through economic responses and recovery programmes; (iv) guiding the necessary surge in fiscal and financial stimulus to make macroeconomic policies work for the most vulnerable and strengthening multilateral and regional responses; (v) promoting social cohesion and investing in community-led resilience and response systems. The policies must be based on environmental sustainability and gender equality (United Nations, 2020c)

Based on the latest ECLAC bulletins on COVID-19 and their recommendations to deal with a situation that, tragically, affects the most vulnerable populations disproportionately, specific recommendations are made in respect of Afrodescendent populations, to:

27 For more information on these recommendations, see CNOA (2020). 
- Tackle the consequences of the pandemic through central and local public policies in which Afrodescendent civil society organizations (community and religious organizations, social movements and local governments) play an active part and have decision-making power.

- Develop emergency responses, based on social protection and a rights and well-being perspective, by implementing universal, redistributive and solidarity policies that are sensitive to differences, especially with regard to the Afrodescendent population.

- Guarantee a minimum income to cope with the pandemic and post-pandemic period (especially in the case of informal and precarious workers); improve health services and provide more social protection; safeguard income and employment; and expand direct cash transfers, unemployment, underemployment and self-employment benefits, and interest-free credit to enable companies to pay wages and defer loan repayment. All this with a special focus on Afrodescendent populations, owing to their greater vulnerability to the pandemic.

- Consider designing labour inclusion strategies and opening special lines of credit to address the distinctive circumstances faced by some of the most vulnerable groups, to enable Afrodescendants to recover during the pandemic. This should be a joint effort by State agencies, civil society and the private sector

- Guarantee universal access to health services, testing, medical care, basic services, housing, food and nutrition security, and education.

- Collect and publish data on people hospitalized, infected and deceased, by ethnicity/race.

- Provide support through policies targeted at the most vulnerable subgroups of the Afrodescendent population: older persons; paid and unpaid caregivers; those living in at-risk areas (communities, slums); homeless people; 28 and those with comorbidities, such as high blood pressure, diabetes, lung disease and sickle cell anaemia (which mainly affects the Afrodescendent population).

- Provide strong support to the most vulnerable populations, especially Afrodescendants, in order to reduce the digital divide, because Afrodescendants are at a disadvantage in this respect, physical distancing will accelerate the automation of some sectors and production processes, and all this will have a major impact on employment.

It is necessary to ensure that all the recommendations are applied to everyone without any form of discrimination, especially on the grounds of ethnicity, race, or socioeconomic or immigration status, as no one should be left behind. Given that Latin American Afrodescendants tend to live in urban areas, which is where the vast majority of reported cases of COVID-19 have occurred, it is necessary and urgent to rethink cities and transform them to respond not only to the current COVID-19 reality but also to any future pandemics. This means bouncing back better, by building more resilient, inclusive and sustainable cities. This pandemic should be used as an opportunity for doing that and, once and for all, laying the necessary foundations to implement a model of sustainable, inclusive and racism-free development in the region.

28 In Brazil, for example, the proportion of Afrodescendants among the homeless (67\%) was substantially higher than that of the general population (44.6\%) (see [online] https://www.ipea.gov.br/portal/images/stories/ PDFs/nota_tecnica/200610_nt_74_diset.pdf). Homeless persons should be provided with toilets and bottled drinking water, community restaurants should be open longer and provide free food handouts, the homeless should be prioritized in vaccination campaigns, health teams should be expanded, hygiene products should be distributed and shelter should be provided to those required to self-isolate. 


\section{Bibliography}

Abramo, L., S. Cecchini and H. Ullmann (2020), "Enfrentar las desigualdades en salud en América Latina: el rol de la protección social", Ciência \& Saúde Coletiva, vol. 25, No. 5, May.

Abramo, L., S. Cecchini and B. Morales (2019), Social programmes, poverty eradication and labour inclusion: lessons from Latin America and the Caribbean, ECLAC Books, No. 155 (LC/PUB.2019/5-P), Santiago, Economic Commission for Latin America and the Caribbean (ECLAC)

Abramo, L., V. Milosavljevic and M. Rangel (2019), "La matriz de la desigualdad social en América Latina y la exclusión de las personas afrodescendientes", Santiago, unpublished.

ATISBA (2020), Hacinamiento urbano y riesgo propagación codvid-19: impactos urbanos + propuestas [online] http://www.atisba.cl/wp-content/uploads/2020/04/ReporteAtisba-Monitor-Hacinamiento-y-Riesgo-Propag-Covid-19.pdf.

BRK Ambiental/Instituto Trata Brasil (2018), Mulheres \& saneamento.

Campello, T. (coord.) (2017), Faces da desigualdade no Brasil: um olhar sobre os que ficam para trás, Brasilia, Latin American Faculty of Social Sciences (FLACSO)/Latin American Social Sciences Council (CLACSO).

CNOA (National Conference of Afro-Colombian Organizations) (2020), "Directrices para responder al COVID 19 para el pueblo y comunidades afrodescendientes en Colombia" [online] https://convergenciacnoa.org/directrices-para-responder-al-covid-19-parael-pueblo-y-comunidades-afrodescendientes-en-colombia/.

Del Popolo, F. and M. Rangel (2011), Juventud afrodescendiente en América Latina: realidades diversas y derechos (in)cumplidos, Panama City, Economic Commission for Latin America and the Caribbean (ECLAC)/United Nations Population Fund (UNFPA).

Duarte, J. D. F. (2020), "Género, cuarentena y covid-19: para una crítica del trabajo doméstico", Pensar la Pandemia: Observatorio Social del Coronavirus, No. 31, Latin American Social Sciences Council (CLACSO)

ECLAC (Economic Commission for Latin America and the Caribbean) (2020a), "Measuring the impact of COVID-19 with a view to reactivation", Special Report COVID-19, No. 2, 21 April.

(2020b), "Afrodescendientes y la matriz de la desigualdad social en América Latina: retos para la inclusión", Santiago, unpublished.

(2020c), Regional Agenda for Inclusive Social Development (LC/CDS.3/5), Santiago.

(2020d), "Addressing the growing impact of COVID-19 with a view to reactivation with equality: new projections", Special Report COVID-19, No. 5, Santiago, July. (2019a), Social Panorama of Latin America, 2019 (LC/PUB.2019/22-P/Rev.1), Santiago. (2019b), Critical obstacles to inclusive social development in Latin America and the Caribbean: background for a regional agenda (LC/CDS.3/3), Santiago. (2019c), Social Panorama of Latin America, 2018 (LC/PUB.2019/3-P), Santiago. (2018a), "Afrodescendent women in Latin America and the Caribbean: debts of equality", Project Documents (LC/TS.2018/33), Santiago, July.

(2018b), "Autonomies", Gender Equality Observatory for Latin America and the Caribbean [online] https://oig.cepal.org/en/autonomies.

(2017a), "Situación de las personas afrodescendientes en América Latina y desafíos de políticas para la garantía de sus derechos", Project Documents (LC/TS.2017/121), Santiago. (2017b), Social Panorama of Latin America, 2016 (LC/PUB.2017/12-P), Santiago. (2017c), Linkages between the social and production spheres: gaps, pillars and challenges (LC/CDS.2/3), Santiago

(2016a), The social inequality matrix in Latin America (LC/G.2690(MDS.1/2)), Santiago. (2016b), Inclusive social development: the next generation of policies for overcoming poverty and reducing inequality in Latin America and the Caribbean (LC. L/4056/Rev.1), Santiago.

(2016c), Social Panorama of Latin America, 2015 (LC/G.2691-P), Santiago, October. 
(2016d), Horizons 2030: equality at the centre of sustainable development (LC/G.2660 (SES.36/3)), Santiago.

(2016e), "Interrelationship of the autonomies", Gender Equality Observatory for Latina America and the Caribbean [online] https://oig.cepal.org/en/autonomies/ interrelationship-autonomies.

(2014), Social Panorama of Latin America, 2014 (LC/G.2635-P), Santiago.

(2013a), "Mujeres indígenas en América Latina: dinámicas demográficas y sociales en el marco de los derechos humanos", Project Documents (LC/W.558), Santiago. (2013b), Montevideo Consensus on Population and Development (LC/L.3697) [online] https://repositorio.cepal.org/bitstream/handle/11362/21860/4/S20131039_en.pdf. (2012a), Structural Change for Equality: An integrated approach to development (LC/G.2524(SES.34/3)), Santiago.

(2012b), Eslabones de la desigualdad: heterogeneidad estructural, empleo y protección social (LC/G.2539-P), Santiago.

(2012c), Social Panorama of Latin America, 2012 (LC/G.2557-P), Santiago.

(2010a), Time for Equality: Closing Gaps, Opening Trails (LC/G.2432(SES.33/3)), Santiago

(2010b), Social Panorama of Latin America, 2010 (LC/G.2481-P), Santiago.

ECLAC/ILO (Economic Commission for Latin America and the Caribbean/International Labour Organization) (2020), Work in times of pandemic: the challenges of the coronavirus disease (COVID-19))", Employment Situation in Latin America and the Caribbean, No. 22 (LC/TS.2020/46), Santiago.

ECLAC/PAHO (Economic Commission for Latin America and the Caribbean/Pan-American Health Organization) (2020), "Health and the economy: A convergence needed to address COVID-19 and retake the path of sustainable development in Latin America and the Caribbean", ECLAC-PAHO COVID-19 Report, Santiago, July

Ferreira, A. P. de S., C. L. Szwarcwald and G. N. Damacena (2019), "Prevalência e fatores associados da obesidade na população brasileira: estudo com dados aferidos da Pesquisa Nacional de Saúde, 2013", Revista Brasileira de Epidemiologia, vol. 22

Fiocruz (Fundación Oswaldo Cruz) (2020), "Covid-19: Fiocruz lança açōes de apoio a populaçōes vulneráveis" [online] https://portal.fiocruz.br/noticia/covid-19-fiocruzlanca-acoes-de-apoio-populacoes-vulneraveis

Government of Peru (2020), "Lineamientos para la incorporación de la variable étnica en los registros administrativos de las entidades públicas en el marco de la emergencia sanitaria declarada por el COVID-19" [online] http://transparencia.cultura.gob.pe/ sites/default/files/transparencia/2020/05/decretos-supremos/ds005-2020-mcanexo.pdf.

Guimarães, A. S. (1999), "Raça e os estudos de relaçōes raciais no Brasil", Novos estudos CEBRAP, São Paulo.

IBGE (Brazilian Institute of Geography and Statistics) (2020), "Brasil: indicadores de saúde" [online] https://COVID-19.ibge.gov.br/pnad-covid/.

IDB (Inter-American Development Bank) (2020), "Exposure and Inequalities: African Descendants During COVID-19" [online] https://blogs.iadb.org/igualdad/en/africandescendants-during-covid-19/.

INFPI (National Institute of Indigenous Peoples) (2020), Guía para la atención de pueblos y comunidades indígenas y afromexicanas ante la emergencia sanitaria generada por el virus SARS-CoV2 (COVID-19), City of Mexico.

IPEA/FBSP (Institute of Applied Economic Research/Brazilian Forum on Public Security) (2019), Atlas da Violência 2019 [online] http://www.ipea.gov.br/portal/images/ stories/PDFs/relatorio_institucional/190605_atlas_da_violencia_2019.pdf.

Ministry of Culture of Peru (2020), "Ministerio de Cultura: se refuerzan mensajes preventivos sobre coronavirus en 10 regiones con población afroperuana" [online] https://www. gob.pe/institucion/cultura/noticias/165868-ministerio-de-cultura-se-refuerza\%20 n-mensajes-preventivos-sobre-coronavirus-en-10-regiones-con-poblacion-afroperuana.

Ministry of Culture of Peru/Group for the Analysis of Development (GRADE) (2015), Estudio especializado de población afroperuana, Lima. 
Ministry of Health of Brazil (2020), "COVID-19 no Brasil" [online] https://susanalitico. saude.gov.br/extensions/covid-19_html/covid-19_html.html\#/dashboard/.

Ministry of Health of Colombia (2020a), "Lineamientos para la prevención, detección y manejo de casos de coronavirus (COVID-19) para población étnica en Colombia" [online] https://www.minsalud.gov.co/RID/asif13-poblacion-etnica-covid-19-t.pdf. (2020b), "Orientaciones para el manejo, traslado y disposición final de cadáveres por SARS-COV-2 (COVID-19)" [online] https://www.minsalud.gov.co/sites/rid/Lists/ BibliotecaDigital/RIDE/VS/ED/VSP/manejo-cadaveres-covid-19f.pdf.

Ministry of Health of Costa Rica (2020), Recomendaciones para la prevención del COVID-19 en población afrodescendiente, San José, 13 April.

OAS (Organization of American States) (2020a), "IACHR and its Special Rapporteurship on ESCER calls on the States to guarantee the rights of Afro-descendant Persons and prevent racial discrimination in the context of the COVID-19 pandemic", Press Release [online] https://www.oas.org/en/iachr/media_center/PReleases/2020/092.asp. (2020b), "Inter-American Network on Afro-descendant Population Policies Warns of Disproportionate Impact of the Pandemic in these Communities", Press Release, 30 April [online] https://www.oas.org/en/media_center/press_release.asp?sCodigo=E-042/20.

Office of the Ombudsperson of Peru (2020), "Situación de personas de especial protección a propósito de la declaratoria de emergencia sanitaria", serie Informes Especiales, No. 12-2020-DP, Lima.

Oglobo (2020), "Costureiras fazem mutirão para produzir máscaras no combate ao novo coronavírus" [online] https://oglobo.globo.com/rio/mutirao-de-costureiras-produzmascaras-de-pano-para-moradores-de-favelas-do-rio-24370006.

$\mathrm{OHCHR}$ (Office of the United Nations High Commissioner for Human Rights) (n/d), "The right to adequate housing and urbanization" [online] https://acnudh.org/ load/2016/10/Adequate-Housing-and-Urbanization_SP.pdf. (2020), "COVID-19 Guidance", Geneva [online] https://www.ohchr.org/EN/NewsEvents/ Pages/COVID-19Guidance.aspx.

PAHO/WHO (Pan American Health Organization/World Health Organization) (2020), Considerations on Indigenous Peoples, Afro-Descendants, and Other Ethnic Groups During the COVID-19 Pandemic, Washington, D.C.

Pires, J. (2020), "Nota Pública Movimento Favelas na Luta", GGN [online] https://jornalggn. com.br/a-grande-crise/nota-publica-movimento-favelas-na-luta/.

(2017), Determinantes sociales de la salud en la región de las Américas, Washington, D.C.

Taschdjian, A. and D. Vásquez (2011), "Un estudio de segregación de los hombres afrodescendientes en el mercado laboral uruguayo", Degree thesis in Economics, Montevideo, University of the Republic of Uruguay.

Telles, E. and L. Steele (2012), "Pigmentocracia en las Américas: ¿cómo se relaciona el logro educativo con el color de piel?", Perspectivas desde el Barómetro de las Américas, No. 73, Princeton University.

UNAS (União de Núcleos, Associaçōes dos Moradores de Heliópolis e Região) (2020), "Costureiras de Heliópolis irão produzir máscaras de proteção ao Covid-19" [online] https://www.unas.org.br/single-post/Costureiras-de-Heliopolis-irao-produzirmascaras-de-protecao-a-COVID-19.

UNFPA (United Nations Population Fund) (2020), "Implications of COVID-19 for the Afrodescendant population in Latin America and the Caribbean", Technical Brief, 28 April.

United Nations (2020a), Plan de Respuesta Humanitaria COVID-19 Honduras, mayo. (2020b), Plan de Respuesta Humanitaria COVID-19 Ecuador, abril.

(2020c), "COVID-19 response", April [online] https://mww.un.org/sustainabledevelopment/ globalpartnerships/ (2017), New Urban Agenda (A/RES/71/256), New York. (2015), "Transforming our world: the 2030 Agenda for Sustainable Development" (A/RES/70/1), New York, October.

(2014), "Proclamation of the International Decade for People of African Descent" (A/RES/68/237), New York [online] https://undocs.org/en/A/RES/68/237. 
(2014b), "Programme of activities for the implementation of the International Decade for People of African Descent", New York [online] https://undocs.org/en/A/ RES/69/16.

(2002), "World Conference Against Racism, Racial Discrimination, Xenophobia and Related Intolerance. Declaration and Programme of Action", New York [online] https://www.ohchr.org/Documents/Publications/Durban_text_en.pdf.

WHO/UNICEF (World Health Organization/United Nations Children's Fund) (2020), "Water, sanitation, hygiene, and waste management for SARS-CoV-2, the virus that causes COVID-19", Interim guidance, 29 July.

Worldometer (2020), "COVID-19 Coronavirus Pandemic" [online] https://www.worldometers info/coronavirus/.

This is one of a set of reports by the Economic Commission for Latin America and the Caribbean (ECLAC) on the evolution and impact of the COVID-19 pandemic in the region. It was prepared by the Latin American and Caribbean Demographic Centre (CELADE) - Population Division of ECLAC, directed by Paulo Saad, under the general coordination of Alicia Bárcena, Executive Secretary of ECLAC.

This report was published thanks to the cooperation of the Government of Germany, through the Federal Ministry for Economic Cooperation and Development (BMZ) and the German Agency for International Cooperation (GIZ).

Copyright (C) United Nations, 2021 